\title{
Volatile organic compounds in the western Mediterranean basin: urban and rural winter measurements during the DAURE campaign
}

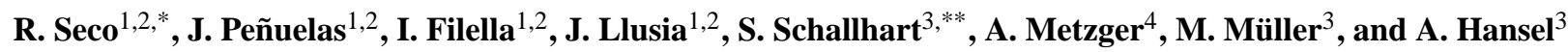 \\ ${ }^{1}$ CREAF, Cerdanyola del Vallès 08193, Catalonia, Spain \\ ${ }^{2}$ CSIC, Global Ecology Unit CREAF-CEAB-UAB, Cerdanyola del Vallès 08193 Catalonia, Spain \\ ${ }^{3}$ Institut für Ionenphysik und Angewandte Physik, Universität Innsbruck, Technikerstrasse 25, 6020 Innsbruck, Austria \\ ${ }^{4}$ Ionicon Analytik, Eduard-Bodemgasse 3, 6020 Innsbruck, Austria \\ * now at: Atmospheric Chemistry Division, National Center for Atmospheric Research, Boulder, CO 80301, USA \\ ** now at: Department of Physics, Division of Atmospheric Sciences P.O. Box 64, Gustaf Hällströminkatu 2, 00014 University \\ of Helsinki, Helsinki, Finland
}

Correspondence to: R. Seco (email@ rogerseco.cat)

Received: 10 September 2012 - Published in Atmos. Chem. Phys. Discuss.: 30 November 2012

Revised: 21 March 2013 - Accepted: 25 March 2013 - Published: 25 April 2013

\begin{abstract}
Atmospheric volatile organic compounds (VOCs) have key environmental and biological roles, but little is known about the daily VOC mixing ratios in Mediterranean urban and natural environments. We measured VOC mixing ratios concurrently at an urban and a rural site during the winter DAURE campaign in the northeastern Iberian Peninsula, by means of PTR-MS at both locations: a PTR-QuadMS at the urban site and a PTR-ToF-MS at the rural site. All VOC mixing ratios measured were higher at the urban site (e.g. acetaldehyde, isoprene, benzene, and toluene with averages up to $1.68,0.31,0.58$ and $2.71 \mathrm{ppbv}$, respectively), with the exception of some short-chain oxygenated VOCs such as acetone (with similar averages of $0.7-1.6 \mathrm{ppbv}$ at both sites). The average diurnal pattern also differed between the sites. Most of the VOCs at the urban location showed their highest mixing ratios in the morning and evening. These peaks coincided with traffic during rush hour, the main origin of most of the VOCs analyzed. Between these two peaks, the sea breeze transported the urban air inland, thus helping to lower the VOC loading at the urban site. At the rural site, most of the measured VOCs were advected by the midday sea breeze, yielding the highest daily VOC mixing ratios (e.g. acetaldehyde, isoprene, benzene, and toluene with averages up to $0.65,0.07,0.19$, and $0.41 \mathrm{ppbv}$, respectively). Only biogenic monoterpenes showed a clear local origin at this site. In addition, the concentrations of fine particulate matter observed at both sites, together with the synoptic meteorological con-
\end{abstract}

ditions and radio-sounding data, allowed the identification of different atmospheric scenarios that had a clear influence on the measured VOC mixing ratios. These results highlight the differences and relationships in VOC mixing ratios between nearby urban and rural areas in Mediterranean regions. Further research in other urban-rural areas is warranted to better understand the urban-rural influence on atmospheric VOC mixing ratios under different atmospheric conditions.

\section{Introduction}

The DAURE (Determination of the Sources of Atmospheric Aerosols in Urban and Rural Environments in the Western Mediterranean) campaign was a multidisciplinary international measurement program conducted in Catalonia (NE Iberian Peninsula) during the winter (February-March) and summer (July-August) of 2009. It focused on identifying the sources of aerosols, the mechanisms of formation of secondary aerosols and the origin of intense episodes of pollution that frequently occur at regional scales in summer and winter in the Western Mediterranean Basin (WMB). Several research teams conducted the study using state-of-theart methods, such as ${ }^{14} \mathrm{C}$ analysis, Proton Transfer Reaction Mass Spectrometry and High Resolution Time-of-Flight Aerosol Mass Spectrometry, and classical techniques for the sampling and analysis of aerosols and volatile organic 
compounds (VOCs). The first results of the campaign have recently been published (e.g. Minguillón et al., 2011; Moreno et al., 2011; Seco et al., 2011b; Mohr et al., 2012; Reche et al., 2012). For detailed information about the campaign, see the overview by Pandolfi et al. (2013).

Of all the measurements performed during the DAURE campaign, those involving VOCs are the focus of our report. VOCs present in the atmosphere have both natural and anthropogenic sources. Emission by vegetation is regarded as the largest natural source on a global scale (Guenther et al., 2006). Atmospheric VOCs and their emissions by vegetation are ecologically important because VOCs can protect plants against high temperatures (Singsaas and Sharkey, 1998; Peñuelas et al., 2005), high irradiance (Peñuelas and Munné-Bosch, 2005), and oxidative stress (Peñuelas and Llusia, 2002; Velikova et al., 2005). They also act as plantplant communication signals (Pierik et al., 2003; Baldwin et al., 2006; Heil and Kost, 2006; Kegge and Pierik, 2010; Seco et al., 2011a). Likewise, biogenic VOCs play a role in plant-animal relationships, such as plant-pollinator relationships (Wright and Schiestl, 2009), direct defense of plants against herbivores and indirect defense through the attraction of the natural enemies of the herbivores (Kessler and Baldwin, 2001; Llusia and Peñuelas, 2001; Pichersky and Gershenzon, 2002). On the other hand, anthropogenic VOCs are released into the atmosphere by human activities, especially those related to vehicular exhausts, evaporation of gasoline, use of solvents, emissions of natural gas and industrial processes (Friedrich and Obermeier, 1999). Even though anthropogenic VOC emissions are quantitatively smaller than biogenic emissions on a global scale, anthropogenic VOCs can be the most abundant VOC species in urban areas, and many are routinely monitored by environmental authorities due to their adverse effects on health (Guerra et al., 1995).

VOCs, whether natural or anthropogenic, also play several key roles in atmospheric chemistry, which make them highly relevant for study. For example, they are implicated in the generation of ozone and aerosols in the troposphere. VOCs, together with nitrogen oxides $\left(\mathrm{NO}_{\mathrm{x}}\right)$ and solar radiation, promote the photochemical formation of tropospheric ozone (Sillman, 1999; Atkinson, 2000). Ozone is an oxidizing pollutant that has negative effects on plants (Fowler et al., 2009; Díaz-de-Quijano et al., 2012), poses a threat to human health (Lippmann, 1993) and acts as a tropospheric greenhouse gas. VOCs are also precursors of atmospheric aerosols (Kavouras et al., 1998; Tunved et al., 2006), which can have significant climate implications (Kulmala et al., 2004; Pacifico et al., 2009). In the context of global change, the relationships among VOCs, atmospheric particles and ozone are important and are currently the subjects of intense scientific research (Peñuelas and Staudt, 2010). These relationships are all involved in biogeochemical cycles and influence other global change drivers in complex feedbacks with the climate (Peñuelas and Llusia, 2003; Arneth et al., 2010).

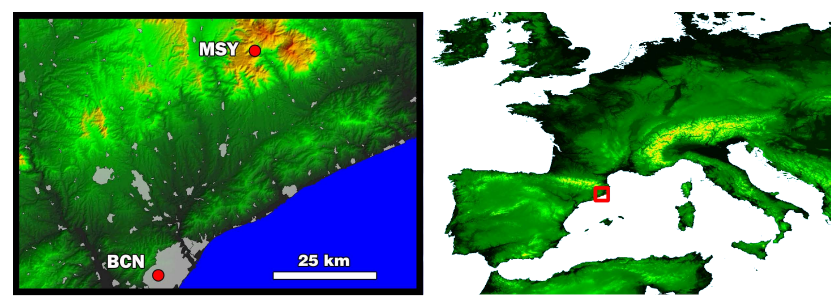

Fig. 1. Location of the urban Barcelona (BCN) and rural Montseny (MSY) measurement sites.

In the Mediterranean area, where the potential for biogenic VOC emissions and photochemistry is high, ozone and particle formation can be elevated, and the ecological role of VOCs can be very significant. Information on tropospheric VOC mixing ratios in the Mediterranean region, however, is scarce. High concentrations of ozone occur here (Gimeno et al., 1995; Ziomas, 1998; Ribas and Peñuelas, 2004; Díaz-deQuijano et al., 2011), and have already damaged plants in the WMB (Sanz et al., 2000; Ribas et al., 2005; Díaz-de-Quijano et al., 2012).

In recent years, Proton Transfer Reaction-Mass Spectrometry (PTR-MS) has enabled the simultaneous measurements of several VOCs, including some oxygenated VOCs that were difficult to measure with other techniques (Seco et al., 2007, 2008). The recent application of PTR-MS technology has determined surface-level VOC mixing ratios in natural areas of boreal and temperate regions (e.g. Spirig et al., 2005; Jordan et al., 2009; Lappalainen et al., 2009) and in urban areas in diverse parts of the world (e.g. Fortner et al., 2009; Langford et al., 2009). Few studies, though, have investigated Mediterranean environments (Filella and Peñuelas, 2006; Davison et al., 2009; Seco et al., 2011b).

In this paper we report the VOC mixing ratios measured during the DAURE winter campaign (February-March 2009) by means of PTR-MS. Measurements of VOC mixing ratios taken at an urban location in Barcelona, together with data for nitrogen oxides and ozone, are compared to those performed simultaneously at a relatively close $(50 \mathrm{~km}) \mathrm{ru}-$ ral site. A comparison of winter and summer VOC data for the rural site has been previously published (see Seco et al., 2011b). Here, we incorporate the winter urban data for a new comparison and analyze both datasets of VOC mixing ratios under the different atmospheric conditions that were identified during the measurement period.

\section{Methods}

\subsection{Measurement sites}

Two locations, an urban-rural pair, were used for the DAURE campaign (Fig. 1). Both sites were within metropolitan Barcelona, a densely populated and industrialized area. The urban Barcelona site (BCN) $\left(41^{\circ} 23^{\prime} 24.01^{\prime \prime} \mathrm{N}, 02^{\circ} 6^{\prime} 58.06^{\prime \prime} \mathrm{E}\right.$, 
Table 1. Mass over charge ratios $(\mathrm{m} / \mathrm{z}$ ) measured with the different PTR-MS systems and the corresponding VOC identities assigned to them. The mean sensitivity and the limit of detection for each VOC are displayed. Sensitivities shown are transmission corrected and normalized to the primary ion signal. All major molecular fragments were considered. Detection limits (DL) were inferred from a signal-to-noise ratio of 2 by $\mathrm{DL}=2 \times \mathrm{SD}_{\text {blank }} /$ sensitivity, with $\mathrm{SD}_{\text {blank }}$ being the standard deviation of background count rates, as reported elsewhere (Karl et al., 2003).

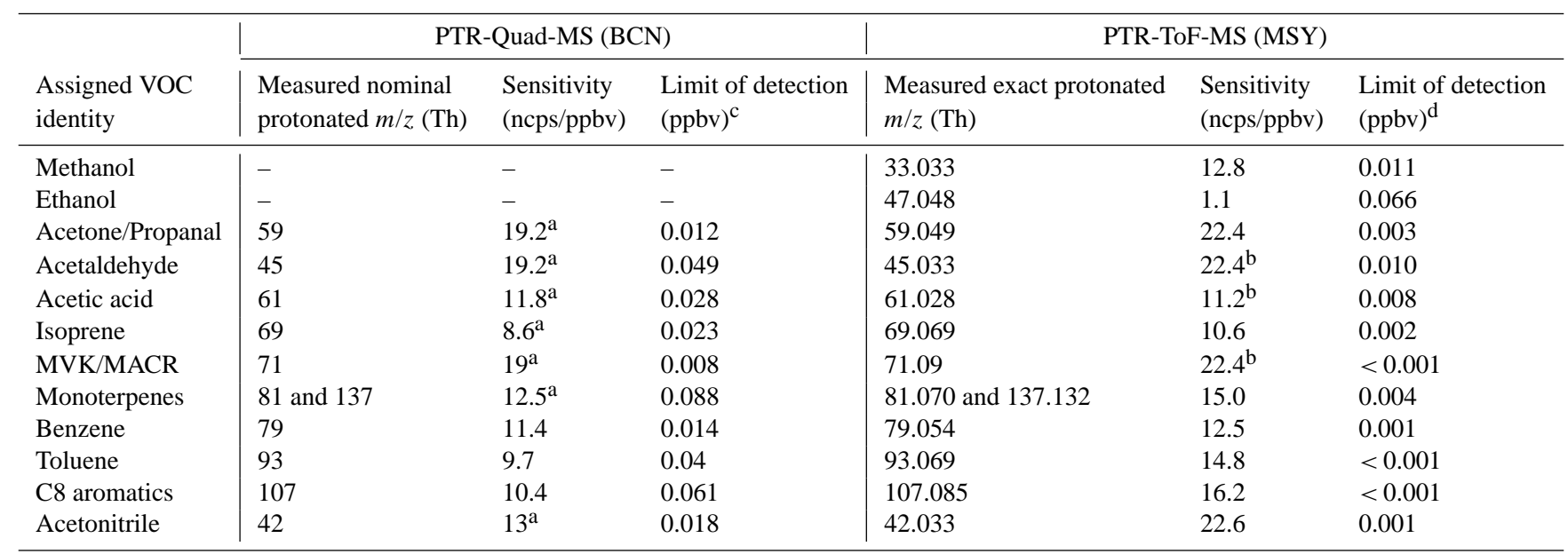

a These sensitivities were not measured in calibrations, but calculated using proton transfer reaction rate coefficients and transmission coefficients.

$\mathrm{b}$ These sensitivities were not measured in calibrations, and acetone sensitivity was used instead (divided by 2 in the case of acetic acid because of the fragmentation on $m / z 43.02$, see Langebner et al., 2013).

c Calculated for an integration time of $2 \mathrm{~s}$.

${ }^{\mathrm{d}}$ Calculated for a $30 \mathrm{~min}$ integration time.

$80 \mathrm{~m}$ a.s.1.) represented the conditions of urban background aerosols. BCN was located in a university garden in western Barcelona, close to Diagonal Avenue, one of the busiest streets of the city, with a daily circulation of 100000 vehicles (Ajuntament de Barcelona, 2007). The rural Montseny site (MSY) was located within a densely forested natural park about $50 \mathrm{~km} \mathrm{NNE}$ of the city of Barcelona and $25 \mathrm{~km}$ from the Mediterranean coast $\left(41^{\circ} 46^{\prime} 45.63^{\prime \prime} \mathrm{N}, 02^{\circ} 21^{\prime} 28.92^{\prime \prime} \mathrm{E}\right.$, $720 \mathrm{~m}$ a.s.1.). MSY represented the conditions of regional background aerosols of the NE Iberian Peninsula. The MSY site is highly representative of the montane holm oak (Quercus ilex L.) forests in the Mediterranean regions of France, Italy, Greece and eastern Spain (Terradas, 1999). See Pandolfi et al. (2013) for more details about the sites and instrumentation used for aerosol monitoring.

\subsection{VOC measurements}

VOC measurements were conducted with two different Proton Transfer Reaction-Mass Spectrometers, one for each site. Both PTR-MS setups sampled ambient air through a heated inlet line ( $4 \mathrm{~m}$ long), made either of deactivated Sulfinert ${ }^{\circledR}$ (MSY) or Teflon ${ }^{\circledR}(\mathrm{BCN})$ tubes, installed at heights of $3 \mathrm{~m}$ above the ground on the front of the house (MSY) or cabin $(\mathrm{BCN})$ where each PTR-MS was installed. The inlet line was filtered with a Teflon ${ }^{\circledR}$ membrane (MSY) or glass wool $(\mathrm{BCN})$ to prevent the intake of dust and other particles. System backgrounds for both instruments were measured approximately every two hours by sampling zero air made by passing air through a catalytic converter (MSY) or a charcoal filter (BCN; model Supelpure HC 1/8", Supelco, USA), and instrument sensitivities were obtained by frequent calibrations with gas standards (Table 1). The charcoal filter used at $\mathrm{BCN}$ was unable to efficiently scavenge methanol from sampled air, so the methanol mixing ratios could not be accurately determined for the $\mathrm{BCN}$ site. Methanol mixing ratios at $\mathrm{BCN}$ will thus not be reported here.

The BCN site was equipped with a High Sensitivity Proton Transfer Reaction Quadrupole Mass Spectrometer (PTRQuad-MS, described by Lindinger et al., 1998), deployed in a cabin in a garden in the university campus. This instrument was operated at $2.14 \mathrm{mbar}, 600 \mathrm{~V}$, and $60^{\circ} \mathrm{C}$ drift tube conditions, producing an $E / N$ ratio of $140 \mathrm{Td}(E=$ electric field strength; $N=$ gas number density; $1 \mathrm{Td}=10^{-17} \mathrm{~V} \mathrm{~cm}^{2}$ ). Sensitivity calibrations for the PTR-Quad-MS were performed by dynamic dilution of an aromatic VOC gas standard (TO-14A, Restek, Bellefonte, PA, USA). The calibration gas contained benzene, toluene, chlorobenzene, dichlorobenzene, styrene, ethyl benzene, xylene, trimethylbenzene, and trichlorobenzene. In addition, vapors of isoprene and monoterpene ( $\alpha$-pinene and limonene) liquid standards were sampled to measure their relative transmission efficiency and their fragmentation pattern. Mixing ratios of VOCs not present in the calibration standard were calculated taking into account the VOC relative transmission, their measured fragmentation pattern and their proton transfer reaction rate coefficients reported elsewhere (Zhao and Zhang, 2004) as described by de Gouw and Warneke (2007). 
For VOC monitoring at MSY, a newly developed Proton Transfer Reaction Time-of-Flight Mass Spectrometer (PTRToF-MS) was deployed in an uninhabited traditional rural house (La Castanya). The house was situated in a forest clearing on a south-facing slope of a mountain, surrounded by a holm oak forest. The PTR-ToF-MS combines a Time-of-Flight MS detector (Tofwerk AG, Switzerland) with the characteristic chemical ionization system that defines PTR systems. A thorough description and characterization of the PTR-TOF instrument is given by Graus et al. (2010) and the data reduction method used is described by Müller et al. (2010). The drift tube of the PTR-ToFMS was operated at $2.3 \mathrm{mbar}, 600 \mathrm{~V}$, and $50^{\circ} \mathrm{C}$, producing an E/N ratio of $130 \mathrm{Td}$. Sensitivity calibrations for the PTR-TOF were performed by dynamic dilution of VOCs using a multi-component gas standard (Apel Riemer Environmental Inc., USA). The calibration gas contained acetone, acetonitrile, acrolein, benzene, 2-butanone, ethanol, formaldehyde, hexanone, isoprene, methanol, monoterpenes ( $\alpha$-pinene), toluene and $o$ - and $p$-xylene. The time-of-flight path length is sensitive to temperature variation, so the mass scale was calibrated continuously by adding dichlorobenzene (protonated $\mathrm{m} / \mathrm{z}=146.9763 \mathrm{Th}$ ) and trichlorobenzene (protonated $m / z=180.9373 \mathrm{Th}$ ) to the PTR-TOF inlet.

These PTR systems differ in the mass resolution of the VOCs analyzed, because the ToF MS is capable of separating isobaric compounds that the PTR-Quad-MS detects as a single mass. Such differences can be seen in Table 1, where the masses measured and the VOC assigned to each $\mathrm{m} / \mathrm{z}$ are displayed. Isobaric VOCs can be distinguished by PTR-ToFMS by their exact masses, while the identification of VOCs by PTR-Quad-MS is liable to isobaric interference. Identification was thus based on calibrations, experience, and wellknown and nearly interference-free VOC-mass correspondences (de Gouw and Warneke, 2007). In the case of different compounds with the same molecular composition (isomers), neither PTR-MS system could distinguish between the different monoterpene isomers at $\mathrm{m} / \mathrm{z} 137$ or between methyl vinyl ketone (MVK) and methacrolein (MACR) at $\mathrm{m} / \mathrm{z}, 71$. Similarly, neither PTR-MS system could distinguish acetone from its isomer propanal at $\mathrm{m} / \mathrm{z} 59$. Since the propanal fraction at $\mathrm{m} / \mathrm{z}, 59$ was likely at least $10 \%$ (a typical value for remote locations), and perhaps more at the $\mathrm{BCN}$ urban site (de Gouw et al., 2003), our reference only to acetone, for simplicity, should be kept in mind.

VOC species reported in this paper are (i) isoprenoids: isoprene and monoterpenes (we also included here two oxidation products of isoprene: methyl vinyl ketone and methacrolein); (ii) short-chain oxygenated compounds (oxVOCs, see Seco et al., 2007 for a review): methanol, acetone, acetaldehyde, acetic acid and ethanol; (iii) aromatic volatiles: benzene, toluene, and C8 aromatics (a term that includes compounds such as xylenes); and (iv) acetonitrile. All VOC mixing ratios are expressed in ppbv $(1 \mathrm{ppbv}=1$ part in $10^{9}$ by volume).

\subsection{Meteorology and measurements of inorganic gaseous pollutants}

At both sites, meteorological data such as temperature, relative humidity, wind direction and speed, precipitation, and solar radiation were gathered from air-monitoring stations operated by the Spanish National Research Council (CSIC). The measurements were taken from towers at a height of $10 \mathrm{~m}$ (Pandolfi et al., 2013). Real-time measurements of ambient-air concentrations of ozone $\left(\mathrm{O}_{3}\right)$ and nitrogen oxides ( $\mathrm{NO}$ and $\mathrm{NO}_{2}$ ) were provided by conventional gasphase air-pollution monitors maintained by the Department of the Environment of the Catalan Government (Generalitat de Catalunya). At MSY, though, NO concentrations were usually below the limit of detection $\left(<1 \mu \mathrm{g} \mathrm{m}^{-3}, 0.8 \mathrm{ppbv}\right)$ of the instrumentation setup deployed by the government. Concentrations of nitrogen oxides were measured by a chemiluminescence analyzer (model 42iTL, Thermo Scientific) and those of ozone by the ultraviolet photometric method (model 48AUV, MCV S.A., Barcelona).

\subsection{Atmospheric scenarios}

For the DAURE campaign, different scenarios of pollution have been identified based on the concentrations of fine particulate matter (PM) observed at both sites, the synoptic meteorological situations and radio-sounding data. The three main winter scenarios (A, B and C) are briefly described here and are depicted in Figs. 2 and 3 by different background colors. The reader is referred to the publications by Pandolfi et al. (2013) and Jorba et al. (2011) for further details of these scenarios.

Scenario A was characterized by the accumulation of air masses during a few days of typical anticyclonic conditions in the WMB, producing an accumulation of pollutants at regional or continental scales, with concentrations of fine PM at MSY comparable or higher than those simultaneously registered at BCN. During scenario A, both BCN and MSY sites were within the planetary boundary layer (PBL). Scenario B was linked with the development of strong thermal inversions that led to extremely high concentrations of pollutants at sea level but without transport towards the mountainous areas. The PBL showed limited vertical development during scenario $\mathrm{B}$, and as a consequence, MSY was above the PBL, and concentrations of PM were low at MSY but highest at BCN. Scenario C occurred when concentrations of PM registered at BCN and MSY were strongly reduced during Atlantic advection, which caused the replacement of the polluted air masses with clean Atlantic air. The main feature of these three winter scenarios is their cyclical pattern in which the A-C-A-BA sequence is repeated during the entire winter campaign. In addition, a fourth transition scenario $(\mathrm{T})$ was identified, occurring occasionally between the main scenarios A, B and C (Figs. 2 and 3). 


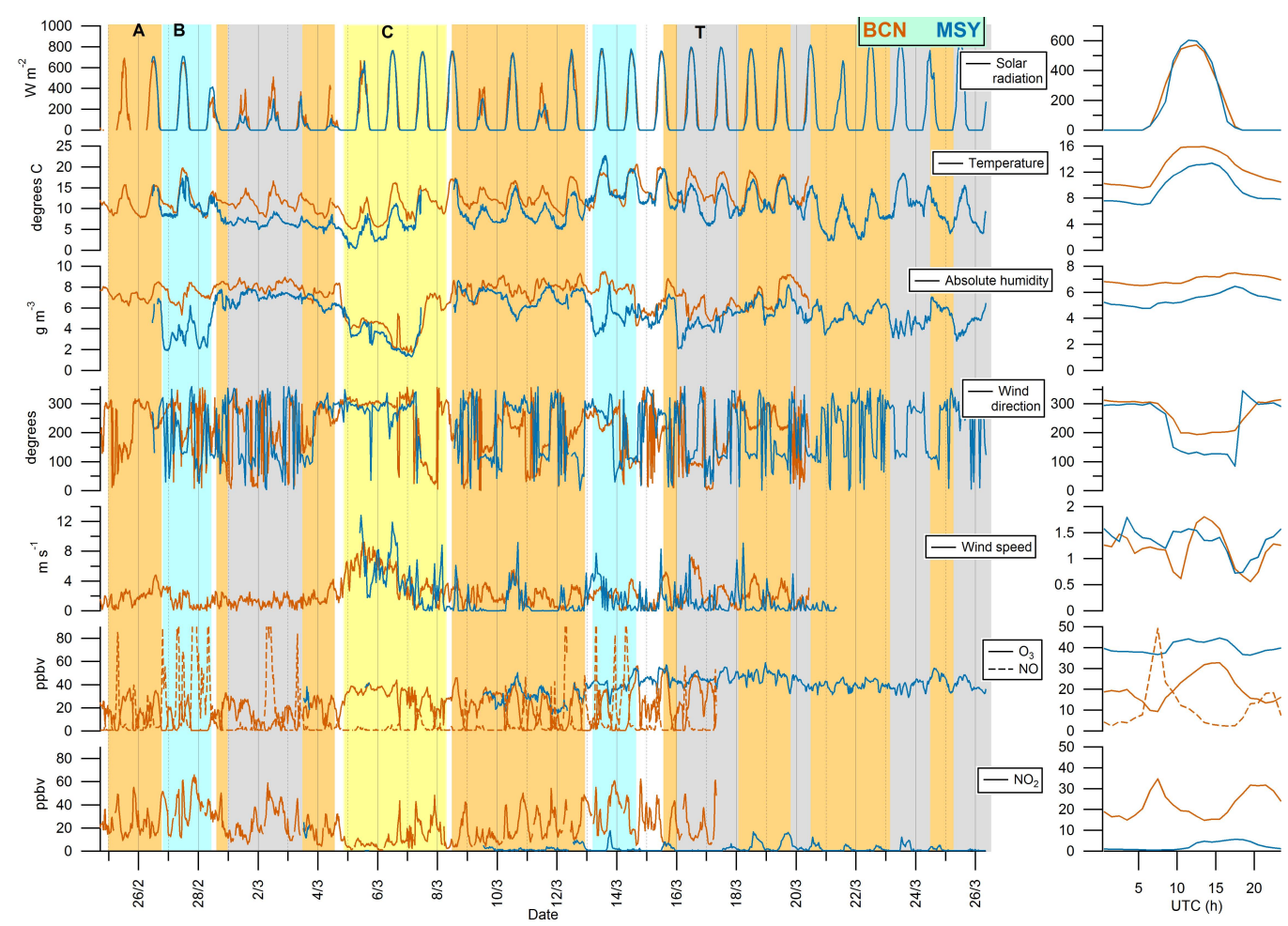

Fig. 2. Left panels: Time series of meteorological parameters (solar radiation, temperature, absolute humidity, wind direction and speed) and of inorganic gaseous pollutants $\left(\mathrm{O}_{3}, \mathrm{NO}_{2}\right.$ and $\mathrm{NO}$ ) measured at $\mathrm{BCN}$ (vermillion traces) and MSY (blue traces). Background colors correspond to the atmospheric scenarios described in Sect. 2.4: A (orange), B (light blue), C (yellow) and T (grey). Date labels indicate 00:00 UTC. Right panels: Hourly averaged diurnal cycles of the entire time series. Please note that, for clarity, NO for MSY is not displayed because its values were usually below the limit of detection $\left(1 \mu \mathrm{g} \mathrm{m}^{-3}, 0.8 \mathrm{ppbv}\right)$.
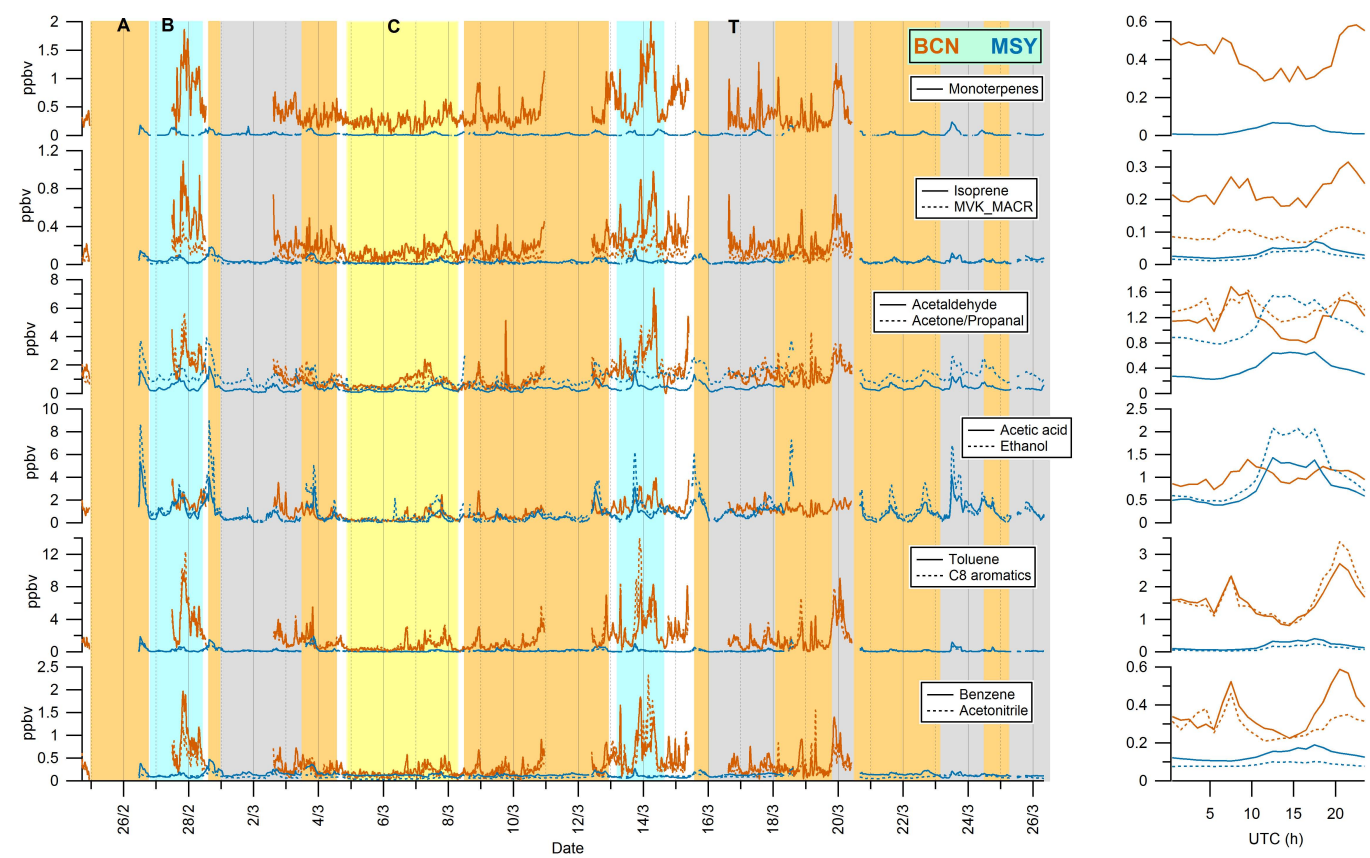

Fig. 3. Left panels: Time series of volatile organic compound mixing ratios measured at BCN (vermillion traces) and MSY (blue traces). Background colors correspond to the atmospheric scenarios described in Sect. 2.4: A (orange), B (light blue), C (yellow) and T (grey). Date labels indicate 00:00 UTC. Right panels: Hourly averaged diurnal cycles of the entire time series. 


\subsection{Data analysis and statistics}

Calculations of VOC mixing ratios from the PTR-MS data, together with the treatment and graphing of the data time series, were conducted using Igor Pro (Wavemetrics Inc., Portland, OR, USA). The correlation coefficients between all the available data variables (VOC mixing ratios, wind, temperature, solar radiation, and $\mathrm{NO}_{2}$ and $\mathrm{O}_{3}$ ) were calculated, in order to conduct a preliminary screening of possible relationships (see the Supplement). For this purpose the Statistica (StatSoft Inc., Tulsa, USA) package was used.

\section{Results and discussion}

\subsection{Meteorological conditions and atmospheric dynamics}

The study area presents a typical Mediterranean climate with temperate winters and irregular rates of precipitation (Pérez et al., 2008). In fact, precipitation was abnormally low during the period reported in this paper, with only small (usually less than $1 \mathrm{~mm}$ per day, and $2.2 \mathrm{~mm}$ on 4 March) events in $\mathrm{BCN}$ between the 1 and 5 March and on the night between 10 and 11 March (data not shown). Average maximum solar radiation reached approximately $600 \mathrm{~W} \mathrm{~m}^{-2}$ at both sites (Fig. 2), and average temperatures differed by about $3{ }^{\circ} \mathrm{C}$ between the two sites $\left(7-13^{\circ} \mathrm{C}\right.$ and $9-16^{\circ} \mathrm{C}$ daily averages at MSY and $\mathrm{BCN}$, respectively), with almost identical daily profiles (Fig. 2). Relative humidity also showed very similar daily profiles, with a difference of about $2 \mathrm{~g} \mathrm{~m}^{-3}$ between the two sites, being higher at BCN (Fig. 2).

Wind was a key factor for understanding the daily evolution of the concentrations of VOCs and other pollutants at both sites. As shown in Fig. 2, patterns of average wind direction and speed at BCN and MSY were very similar. Driven by the solar radiation, sea and mountain breezes began to develop around 07:00 UTC: wind speed increased and wind direction changed to reach an average of 200 degrees at BCN and of 125 degrees at MSY between 09:00 and 10:00 UTC. These southerly wind directions moved the air masses inland during the day from the coast (BCN) to the Barcelona metropolitan region and to rural areas (MSY), transporting VOCs and other pollutants with them. Wind direction and speed began to change around 18:00 UTC, decreasing speed and turning to a northerly direction that stayed more or less constant throughout the night. The importance of mesoscale circulation (i.e. mountain and sea breezes) in the transport of ozone and photochemical precursors (VOCs and $\mathrm{NO}_{\mathrm{x}}$ ) between urban areas and nearby mountainous rural areas, as highlighted by this study, has been confirmed in several other locations worldwide, such as for example Portugal (Monteiro et al., 2012), Taiwan (Tsai et al., 2008) and Hong Kong (Guo et al., 2012).

\section{2 $\mathrm{NO}, \mathrm{NO}_{2}$ and $\mathrm{O}_{3}$ mixing ratios}

These inorganic gaseous pollutants showed distinct diurnal patterns and markedly different mixing ratios at BCN compared to MSY (Fig. 2). The mixing ratios of nitrogen oxides $\left(\mathrm{NO}_{\mathrm{x}}\right)$ were higher at $\mathrm{BCN}$, with daily peaks around 07:0008:00 UTC (maximum averages of 34 and $49 \mathrm{ppbv}$ for NO and $\mathrm{NO}_{2}$, respectively) and 19:00-23:00 UTC. These $\mathrm{NO}_{\mathrm{x}}$ peaks not surprisingly coincided with rush hour, as these gases are mainly produced by combustion engines. $\mathrm{NO}_{2}$ at MSY had maximum averages of less than $6 \mathrm{ppbv}$, and those maximum mixing ratios did not coincide with rush hour. The MSY valley has little traffic, and the sea breezes transport the polluted air masses from the metropolitan region of Barcelona to the site during the afternoon.

Ozone showed a similar diurnal cycle at both sites, having the maximum mixing ratios (of about $32 \mathrm{ppbv}$ for $\mathrm{BCN}$ and 44 ppbv for MSY) during the central part of the day (Fig. 2). Especially at $\mathrm{BCN}$, when $\mathrm{NO}_{\mathrm{x}}$ mixing ratios increased due to traffic-related emission, ozone mixing ratios dropped in clear indication of NO titration. Ozone mixing ratios at MSY were higher than at $\mathrm{BCN}$, even at night. Ozone is produced by reactions of $\mathrm{NO}_{\mathrm{x}}$ with VOCs under solar radiation, and such reactions occur not only where $\mathrm{NO}_{\mathrm{x}}$ and VOCs are emitted, but also particularly during the transport of the air mass inland, thus yielding higher concentrations of ozone at the rural site after several hours of reactions (Sillman, 1999). Moreover, the presence of $\mathrm{VOC}: \mathrm{NO}_{\mathrm{x}}$ ratios more favorable for ozone production during transport and the lack at the MSY site of ozone scavenging by reaction with freshly emitted NO may have contributed to the higher ozone mixing ratios at MSY (see Supplement and Seco et al., 2011b). The presence of these higher concentrations of ozone at MSY compared to $\mathrm{BCN}$ agrees with other studies that reported increased ozone concentrations at higher altitudes (Ribas and Peñuelas, 2006; Díaz-de-Quijano et al., 2009; Evtyugina et al., 2009; Guo et al., 2012).

\subsection{VOC mixing ratios}

VOC mixing ratios were almost always higher at $\mathrm{BCN}$ (Table 2 and Fig. 3). Only acetone and acetic acid showed similar mixing ratios at both sites. Aromatic compounds, mainly toluene and $\mathrm{C} 8$ aromatics, were the most abundant VOCs in the urban atmosphere, with peaks of up to $14 \mathrm{ppbv}$ for toluene. The short-chain alcohols, methanol and ethanol, were the most abundant at the rural site, with peaks close to $10 \mathrm{ppbv}$ for methanol. Unfortunately, methanol and ethanol could not be properly quantified at the urban site, as explained in Sect. 2.2, but based on the measured data (not shown), methanol may have been one of the most abundant VOCs, as has been reported for other urban or suburban regions (Filella and Peñuelas, 2006; Langford et al., 2009, 2010). 
Table 2. Minimum and maximum VOC mixing ratios (ppbv) recorded at BCN and MSY stations during the winter campaign. These numbers correspond to the data displayed in Fig. 3. The data for MSY were previously reported in Seco et al. (2011b).

\begin{tabular}{|c|c|c|c|c|c|c|c|c|}
\hline \multirow[b]{2}{*}{ VOC } & \multicolumn{4}{|c|}{$\mathrm{BCN}$} & \multicolumn{4}{|c|}{ MSY } \\
\hline & Minimum & Maximum & $\begin{array}{c}\text { Hourly } \\
\text { averages } \\
\text { minimum }\end{array}$ & $\begin{array}{c}\text { Hourly } \\
\text { averages } \\
\text { maximum }\end{array}$ & Minimum & Maximum & $\begin{array}{c}\text { Hourly } \\
\text { averages } \\
\text { minimum }\end{array}$ & $\begin{array}{c}\text { Hourly } \\
\text { averages } \\
\text { maximum }\end{array}$ \\
\hline Methanol & - & - & - & - & 0.256 & 9.761 & 1.279 & 2.704 \\
\hline Ethanol & - & - & - & - & $<0.066$ & 8.950 & 0.474 & 2.083 \\
\hline Acetone/Propanal & 0.198 & 5.960 & 1.131 & 1.645 & 0.257 & 3.897 & 0.787 & 1.547 \\
\hline Acetaldehyde & $<0.049$ & 7.400 & 0.804 & 1.688 & 0.071 & 1.885 & 0.227 & 0.657 \\
\hline Acetic acid & 0.091 & 3.960 & 0.728 & 1.389 & 0.026 & 5.348 & 0.393 & 1.428 \\
\hline Isoprene & $<0.023$ & 1.090 & 0.176 & 0.315 & 0.003 & 0.184 & 0.019 & 0.071 \\
\hline MVK/MACR & $<0.008$ & 0.459 & 0.068 & 0.115 & 0.002 & 0.153 & 0.011 & 0.047 \\
\hline Monoterpenes & $<0.088$ & 2.000 & 0.284 & 0.583 & $<0.004$ & 0.234 & 0.005 & 0.067 \\
\hline Benzene & 0.038 & 1.970 & 0.225 & 0.588 & 0.059 & 0.470 & 0.105 & 0.190 \\
\hline Toluene & $<0.04$ & 9.700 & 0.805 & 2.711 & 0.001 & 1.903 & 0.057 & 0.408 \\
\hline C8 aromatics & $<0.061$ & 14.000 & 0.861 & 3.386 & 0.003 & 1.328 & 0.031 & 0.249 \\
\hline Acetonitrile & $<0.018$ & 2.320 & 0.209 & 0.460 & 0.027 & 0.258 & 0.075 & 0.101 \\
\hline
\end{tabular}

The average diurnal cycles of VOC mixing ratios showed a characteristic pattern at each site (Fig. 3), intimately linked to the wind direction and speed at each site. In short, the diurnal cycles of VOC mixing ratios at each site behaved like those of $\mathrm{NO}_{\mathrm{x}}$ described in the previous section.

\subsubsection{BCN urban site}

At BCN, all VOCs peaked in the morning and evening and had lower mixing ratios between these two peaks, when the sea breeze transported the air masses inland and the height of the PBL rose during the day, which helped to dilute the VOC mixing ratios (see correlations in Table S1 of the Supplement). Aromatics have a well-known traffic-related origin (Hsieh et al., 1999; Yamamoto et al., 2000) and they normally peak during rush hour. The combustion of fossil fuels is also a minor global source of acetonitrile (Holzinger et al., 2001a) and may be the dominant source of acetonitrile at BCN during those peaks. Despite acetonitrile's long atmospheric lifetime that allows its long-range transport and may dampen its atmospheric concentration fluctuations, our data show clear peaks during rush hour, especially in the morning, which suggest its main emission source at $\mathrm{BCN}$ are vehicle exhausts. Other VOCs, however, are usually not as directly linked to vehicular emissions as are the aromatics. In fact, their morning and evening peaks were generally not as sharply defined as those of aromatic VOCs (Fig. 3), suggesting that other sources or processes may also play a role. Short-chain oxVOCs have multiple atmospheric sources, such as direct emissions by vegetation (Seco et al., 2007; Filella et al., 2009) and vehicles (Chebbi and Carlier, 1996; Possanzini et al., 2002) and secondary production by the degradation of other VOCs, including those emitted by motor vehicles (Seco et al., 2007). Short-chain oxVOCs also have different atmo- spheric lifetimes, which may explain some of the differences observed in their average diurnal cycles. Acetaldehyde, for example, lasts just a few hours in the air (Possanzini et al., 2002) and is the ox VOC with the sharpest difference of mixing ratios between the rush hour peaks and midday (Fig. 3) since after its direct emission from motor vehicles - or secondary formation after degradation of other primarily emitted VOCs - it is scavenged faster from the atmosphere. On the other hand, oxVOCs like methanol, acetone, and acetic acid can be around for more than a week (Chebbi and Carlier, 1996; Singh et al., 2004; Jacob et al., 2005) and this long lifetime could explain why the maximum mixing ratios found at the rural MSY site, after advection of air masses from urban areas, are of similar magnitude to those measured at the urban BCN site (Fig. 3).

Among the isoprenoids, usually considered to be of mainly biogenic origin, isoprene also has known anthropic sources, e.g. automobile exhaust, which can be important in urban areas such as BCN, especially in winter (Borbon et al., 2001; Barletta et al., 2005; Hellén et al., 2012). As shown in Fig. 3, maximum mixing ratios of isoprene happen during rush hour. This fact suggests that most of the isoprene detected at BCN is of anthropic origin too. A similar case is that of monoterpenes, usually considered biogenic-only VOCs. Traffic-related origin of monoterpenes has been proposed by a study in northern Europe (Hellén et al., 2012), based on the fact that the diurnal cycle of monoterpenes resembled that of aromatics. In our study, we also observed an increase during rush hour, which suggests a traffic origin. However, the mixing ratios did not decrease after the evening rush hour, and the highest mixing ratios of monoterpenes at BCN occurred at night (Fig. 3). This observation suggests that the lowering of the PBL, the cessation of photochemical destruction and the dropping sea breezes could 
favor the accumulation of monoterpenes at night. Obviously, other biogenic sources for monoterpenes cannot be ruled out. The trees, which included pines, of the small urban park where the measuring station was installed may have been the source of these monoterpenes. Also, air masses are transported during the night from the nearby Collserola mountains (located only about $1 \mathrm{~km}$ away), which have important stands of pine (Pinus halepensis Mill. and P. pinea L.) forests. Pines emit monoterpenes not only in response to light but also to temperature (Peñuelas and Llusia, 2001), and nocturnal temperature-dependent emissions of stored monoterpenes from pine forests have previously been described at Mediterranean locations (Davison et al., 2009).

Published reports of VOC mixing ratios in other urban areas of the world are summarized in Table 5. The mixing ratios of aromatic VOCs at BCN were clearly lower than those detected in Mexico City, Caracas, Los Angeles, Athens, Munich and cities in China. For oxVOCs, the mixing ratios of acetaldehyde at $\mathrm{BCN}$ were lower than those reported for most of the cities in Table 5 where data for acetaldehyde was available. For isoprenoids, the mixing ratios of isoprene at $\mathrm{BCN}$ were in the same range of those reported for most of the other cities, except for Mexico City where isoprene and monoterpene mixing ratios were higher.

\subsubsection{MSY rural site}

The diurnal cycles of VOCs at MSY were also similar to those of $\mathrm{NO}_{\mathrm{x}}$ (Fig. 3). All VOC mixing ratios increased after the sea breeze had developed and advected the air masses from the coastal plains and the metropolitan area of Barcelona to MSY. The only VOCs that began to rise before the breeze developed were the monoterpenes, because of their local biogenic origin, but their diurnal patterns were also highly influenced by the characteristics of the wind. The average diurnal pattern of isoprene was similar to that of the other VOCs, mainly because the forests at MSY are largely dominated by holm oak, which emits isoprene at a rate less than $5 \%$ of its monoterpene emission (Peñuelas et al., 2009). The mixing ratios of monoterpenes and isoprene were similarly low at MSY (maxima near 0.2 ppbv and maximum averages near 0.07 ppbv; Table 2). So these isoprenoid VOCs, normally considered predominantly biogenic, surprisingly had higher mixing ratios at BCN than at MSY. It is not the first time that higher urban mixing ratios of isoprenoids compared to a rural site are reported. Hellén et al. (2012) found greater isoprenoid mixing ratios during winter in Helsinki (Finland) than at a rural forested site, attributing the urban isoprenoids mainly to anthropic origin and the rural lower mixing ratios to low biogenic emissions. This matches the situation that we observed during this winter DAURE campaign. As previously stated, the emission of isoprene by the dominant tree species at MSY, holm oak, was very low, as were emissions from other anthropogenic sources that are more relevant in urban locations. The low, seasonal emission rates of monoterpenes from the leaves of holm oaks reported for this winter period (Llusia et al., 2012) partly explain why monoterpene mixing ratios were not very high at MSY. In summer, though, both emission rates and atmospheric mixing ratios of monoterpenes increased by one order of magnitude (Seco et al., 2011b), while the summer monoterpene mixing ratios at $\mathrm{BCN}$ were in the same range as those in winter (data not shown). The case for isoprene in summer was similar, with the same range of mixing ratios at $\mathrm{BCN}$ (data not shown) and an order of magnitude increase of mixing ratios at MSY, the latter probably due to the larger biotic sources of isoprene at MSY (Seco et al., 2011b). For further information on sources and average diurnal cycles of VOCs measured at MSY, both in winter and summer, see Seco et al. (2011b).

\subsubsection{Benzene : toluene ratios}

Benzene and toluene have been used to gauge the photochemical age of an air mass (Warneke et al., 2007). The benzene: toluene ratio of an air parcel tends to increase over time because toluene is scavenged more quickly than benzene by reaction with the $\mathrm{OH}$ radical. Toluene has a higher reaction rate with the $\mathrm{OH}$ radical and thus has a shorter duration than benzene. The hourly average benzene : toluene ratio at $\mathrm{BCN}$ ranged between 0.18 (at night) and 0.29 (early afternoon). These values are lower than those reported for primary exhaust emissions (Heeb et al., 2000) or the 0.410.83 range reported in other cities (Langford et al., 2009). They are, though, within the range measured close to roads in Italy (Steinbacher et al., 2005) and in a suburban area near Barcelona city (Filella and Peñuelas, 2006). The values of this ratio at $\mathrm{BCN}$ could indicate that, apart from vehicular sources of these aromatic compounds, industrial emissions may have some degree of influence. Industrial emissions have been associated with lower benzene : toluene ratios in other studies (Steinbacher et al., 2005; Fortner et al., 2009).

Average benzene : toluene ratios at MSY were in the range between 0.46 (midday and afternoon) and 1.8 (night), and were thus higher than at $\mathrm{BCN}$. As expected, due to photochemical processing, the ratio of the air mass advected by the sea breeze in the afternoon was higher than the ratio at the source of the traffic emissions near the coast and the coastal plains $(\mathrm{BCN})$. Despite the suggestion that a longer time post-emission may be required to substantially change this ratio (Warneke et al., 2001), our results show that the average benzene : toluene ratio of the air mass arriving at MSY was higher than the ratio at $\mathrm{BCN}$ or the ratio at a suburban area between BCN and MSY (Filella and Peñuelas, 2006).

\subsection{Atmospheric scenarios and VOCs}

The data parsed into each of the atmospheric scenarios and the average diurnal cycles of VOCs and inorganic gases computed for each scenario are presented in Figs. 4-8 and 

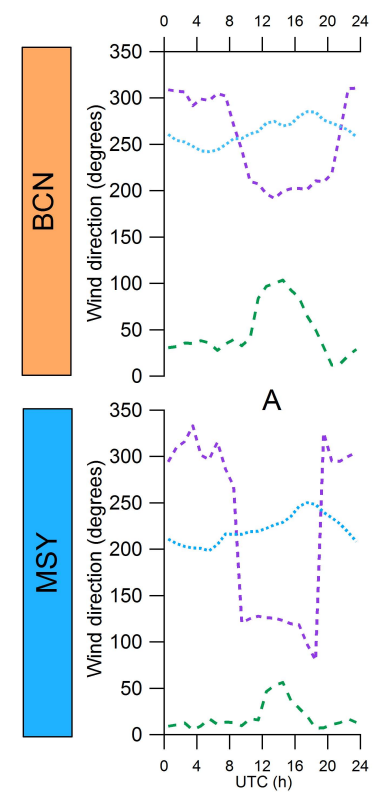

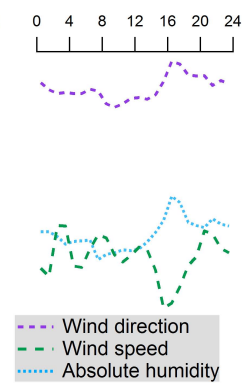

C
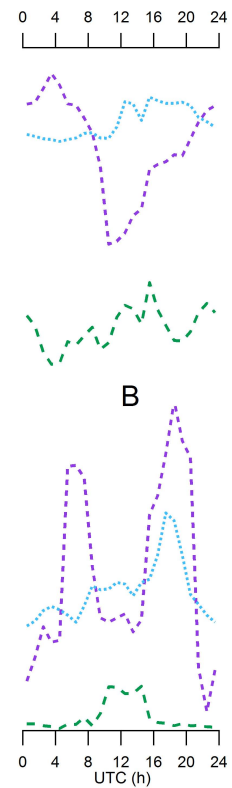

Absolute hy
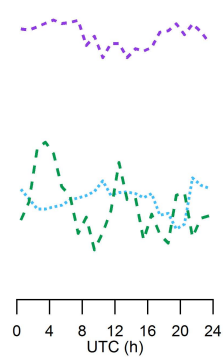

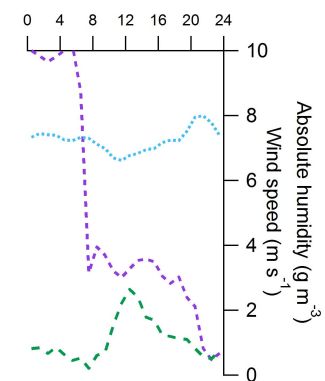

$\mathrm{T}$

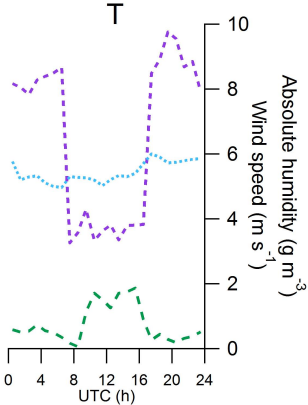

Fig. 4. Average wind direction and speed, and average absolute humidity for each atmospheric scenario at BCN (top panels) and MSY (bottom panels).
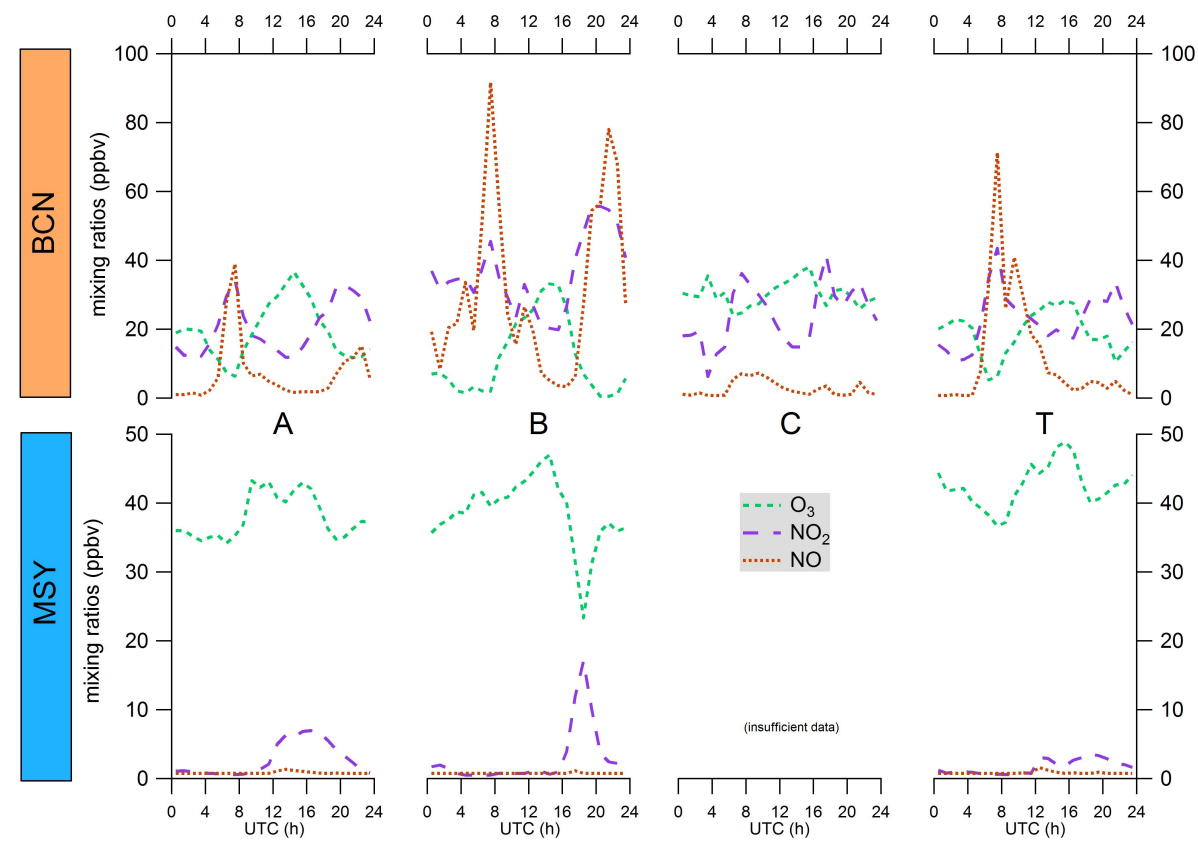

Fig. 5. Average $\mathrm{NO}, \mathrm{NO}_{2}$ and $\mathrm{O}_{3}$ mixing ratios for each atmospheric scenario at BCN (top panels) and MSY (bottom panels). Note the different scaling between top and bottom panels.

Tables 3 and 4. Although the averages for scenario $\mathrm{T}$ are also displayed in these figures and tables, the following discussion will focus on the main scenarios A, B, and C.

\subsubsection{Scenario A}

The average diurnal cycle for scenario A, in terms of mixing ratios and diurnal patterns, resembles the average daily cycle of the entire dataset discussed earlier, especially for MSY. The morning and evening VOC peaks at the BCN site, however, were not as well defined. The highest mixing ratios for isoprene and monoterpenes (Fig. 6) occurred at night, probably when the drainage flows began to blow from the forested Collserola mountains. The main peaks for benzene and toluene also occurred during the evening and at night 

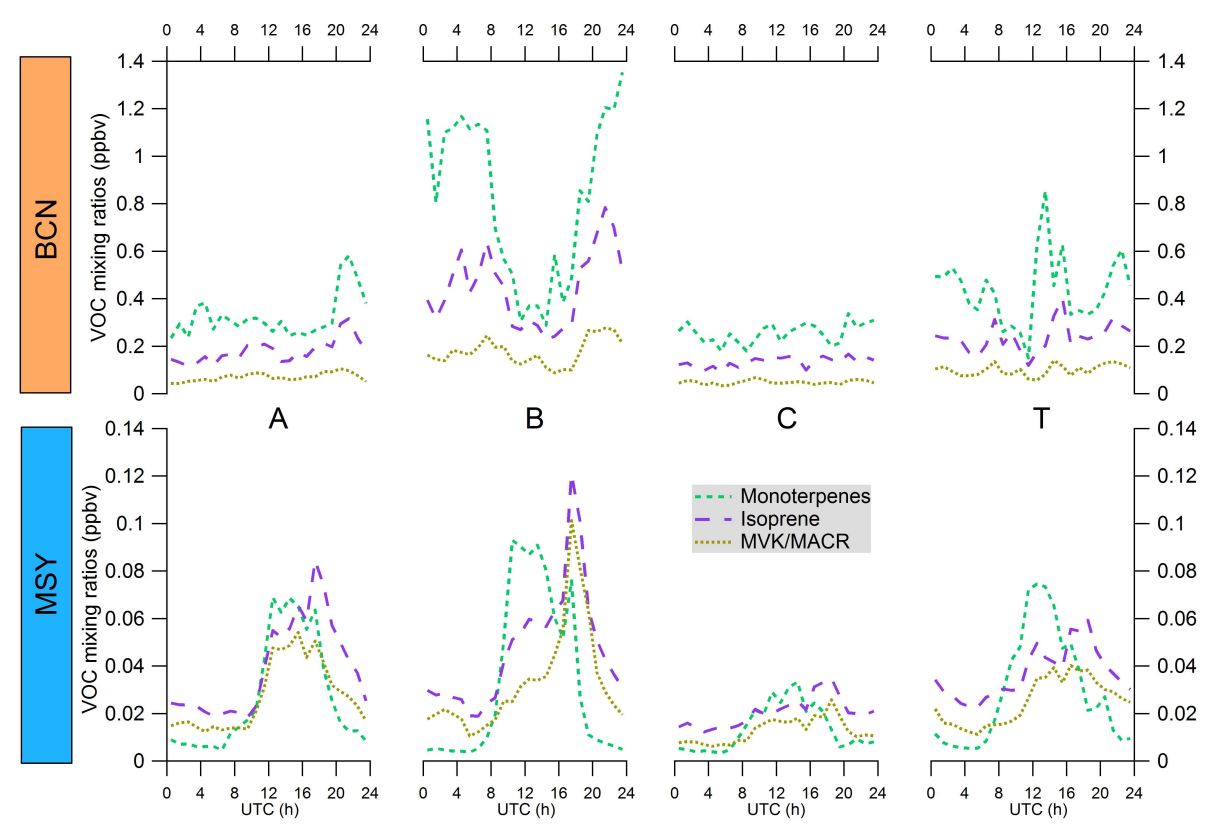

Fig. 6. Average isoprenoid VOC (and MVK/MACR) mixing ratios for each atmospheric scenario at BCN (top panels) and MSY (bottom panels). Note the different scaling between top and bottom panels (one order of magnitude).
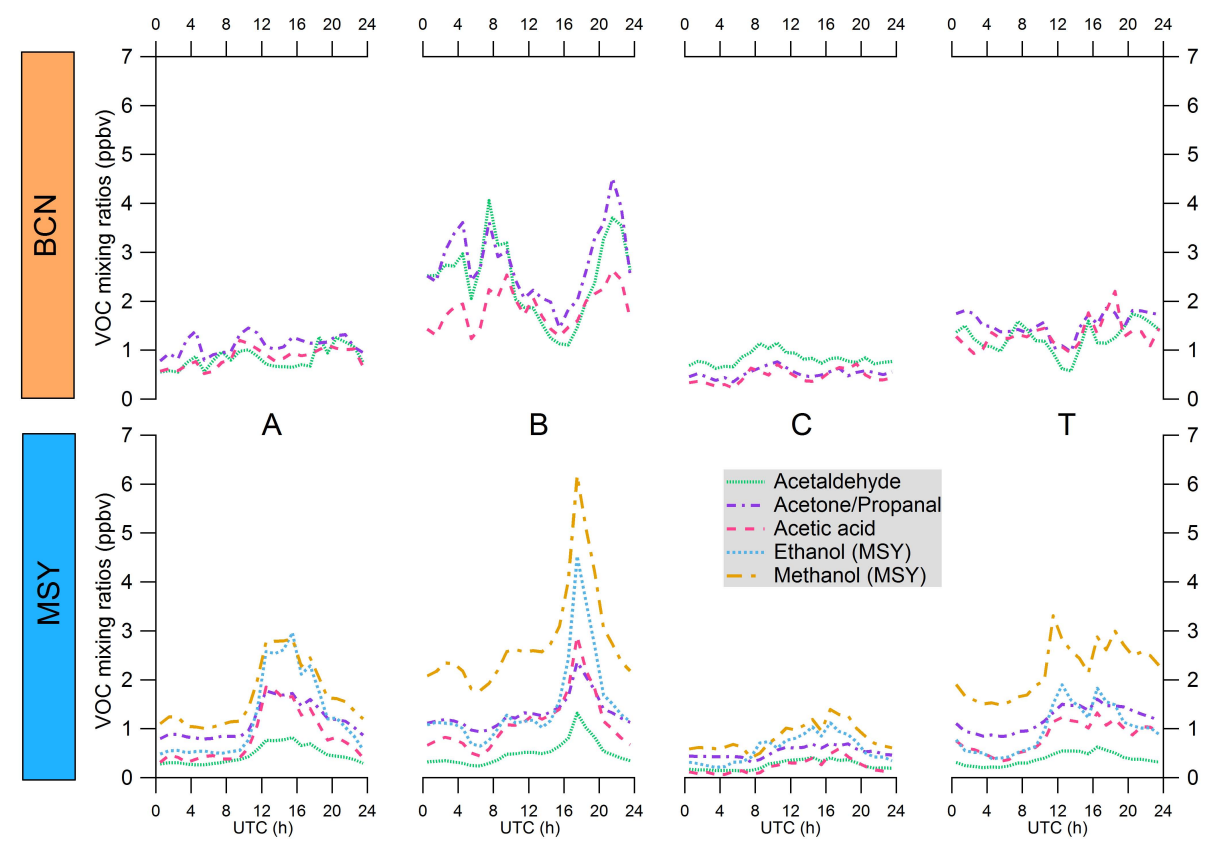

Fig. 7. Average short-chain oxygenated VOC mixing ratios for each atmospheric scenario at BCN (top panels) and MSY (bottom panels).

(Fig. 8). Short-chain oxVOCs showed no clear main peak throughout the day (Fig. 7).

All VOC mixing ratios at MSY rose around 10:00 UTC, when the sea breezes developed and advected air masses from the Barcelona metropolitan region. When the sea breeze stopped, all VOC mixing ratios began to decline (Figs. 6-8).

\subsubsection{Scenario B}

Scenario B occurred when strong thermal inversions decoupled the atmospheres of the two sites, leaving MSY above the PBL and enhancing the accumulation of pollutants at BCN. As a result, $\mathrm{NO}_{\mathrm{x}}$ and $\mathrm{VOC}$ mixing ratios at the $\mathrm{BCN}$ site were the highest measured during the campaign (Figs. 58), as has also been reported for particulate matter (Pandolfi 


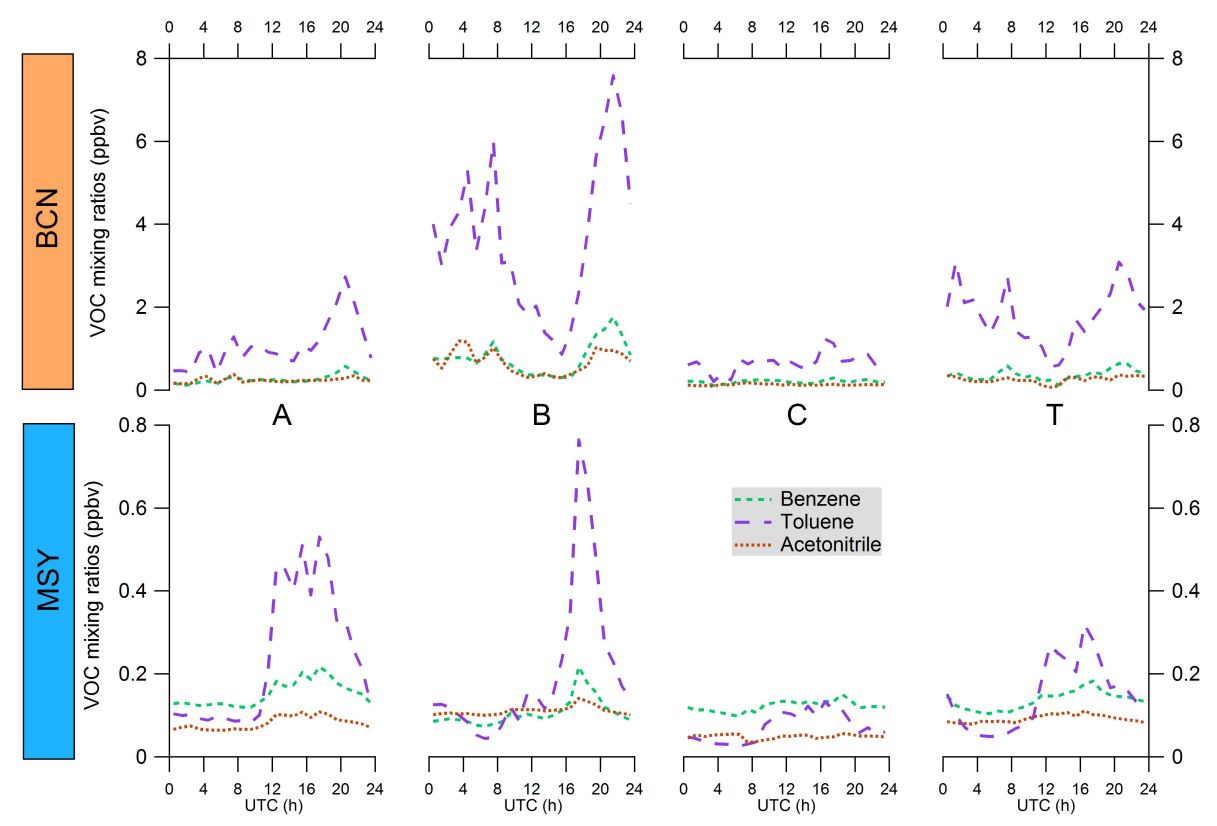

Fig. 8. Average aromatic VOC and acetonitrile mixing ratios for each atmospheric scenario at BCN (top panels) and MSY (bottom panels). Note the different scaling between top and bottom panels (one order of magnitude).

Table 3. Minimum and maximum hourly averaged VOC mixing ratios (ppbv) recorded at the BCN station during each of the atmospheric scenarios (A, B, C, T) described in Sect. 2.4. These values correspond to the data displayed in Figs. 6-8.

\begin{tabular}{|c|c|c|c|c|c|c|c|c|}
\hline \multirow[b]{2}{*}{$\mathrm{BCN}$} & \multicolumn{2}{|c|}{$\mathrm{A}$} & \multicolumn{2}{|c|}{$\begin{array}{c}\text { B } \\
\text { Hourly averages }\end{array}$} & \multicolumn{2}{|c|}{$\begin{array}{c}\text { C } \\
\text { Hourly averages }\end{array}$} & \multicolumn{2}{|c|}{$\begin{array}{c}\mathrm{T} \\
\text { Hourly averages }\end{array}$} \\
\hline & Minimum & Maximum & Minimum & Maximum & Minimum & Maximum & Minimum & Maximum \\
\hline Acetone/Propanal & 0.777 & 1.451 & 1.452 & 4.518 & 0.353 & 0.762 & 0.968 & 1.855 \\
\hline Acetaldehyde & 0.548 & 1.272 & 1.107 & 4.061 & 0.626 & 1.149 & 0.574 & 1.741 \\
\hline Acetic acid & 0.520 & 1.203 & 1.238 & 2.634 & 0.223 & 0.721 & 0.931 & 2.201 \\
\hline Isoprene & 0.115 & 0.316 & 0.228 & 0.783 & 0.091 & 0.166 & 0.119 & 0.401 \\
\hline MVK/MACR & 0.043 & 0.105 & 0.088 & 0.277 & 0.033 & 0.067 & 0.057 & 0.140 \\
\hline Monoterpenes & 0.235 & 0.581 & 0.288 & 1.353 & 0.180 & 0.337 & 0.151 & 0.854 \\
\hline Benzene & 0.117 & 0.573 & 0.301 & 1.763 & 0.114 & 0.298 & 0.119 & 0.643 \\
\hline Toluene & 0.412 & 2.729 & 0.862 & 7.584 & 0.209 & 1.235 & 0.564 & 3.089 \\
\hline $\mathrm{C} 8$ aromatics & 0.478 & 3.289 & 0.869 & 12.273 & 0.274 & 1.363 & 0.662 & 3.397 \\
\hline Acetonitrile & 0.151 & 0.383 & 0.299 & 1.183 & 0.102 & 0.181 & 0.066 & 0.366 \\
\hline
\end{tabular}

et al., 2013). Hourly average maxima reached $1.3 \mathrm{ppbv}$ for monoterpenes, $0.8 \mathrm{ppbv}$ for isoprene, $12 \mathrm{ppbv}$ for $\mathrm{C} 8$ aromatics, $7.5 \mathrm{ppbv}$ for toluene and more than $4 \mathrm{ppbv}$ for acetone and acetaldehyde (Table 3 ). The shape of the diurnal cycle and the mixing ratios registered for VOCs at $\mathrm{BCN}$ during scenario B had a large influence on the shape and mixing ratios of the mean diurnal cycles for the entire dataset, with two main peaks, one in the morning and one in the evening (Fig. 3).

At MSY, only the isoprenoid average diurnal pattern of mixing ratios resembled that of scenario A or of the entire dataset average. Mixing ratios of monoterpenes, with their local biotic origin, and isoprene, perhaps also because of its nearby biotic origin, rose in the morning when the wind direction changed (Fig. 6). In scenario B, the duration of the midday southeasterly wind direction was shorter (Fig. 4) than the average period for the entire campaign or for scenarios A or T. The mixing ratios of oxVOCs and aromatics increased very little during this period of southeasterly wind (Figs. 7 and 8), because the sea breezes did not reach MSY above the PBL and therefore did not advect air parcels from the Barcelona coastal region. Interestingly, an evening peak was detected for all VOCs and $\mathrm{NO}_{2}$ on 13 March that is clearly visible in the average diurnal cycles of scenario B. This peak had a large influence on the averages for scenario B due to the fact that such averages are based on less than four complete days. On 13 March, the wind began to shift again to northerly direction around 14:00-15:00 UTC, 
Table 4. Minimum and maximum hourly averaged VOC mixing ratios (ppbv) recorded at the MSY station during each of the atmospheric scenarios (A, B, C, T) described in Sect. 2.4. These values correspond to the data displayed in Figs. 6-8.

\begin{tabular}{|c|c|c|c|c|c|c|c|c|}
\hline \multirow[b]{2}{*}{ MSY } & \multicolumn{2}{|c|}{$\begin{array}{c}\text { A } \\
\text { Hourly averages }\end{array}$} & \multicolumn{2}{|c|}{$\begin{array}{c}\text { B } \\
\text { Hourly averages }\end{array}$} & \multicolumn{2}{|c|}{$\begin{array}{c}\text { C } \\
\text { Hourly averages }\end{array}$} & \multicolumn{2}{|c|}{$\begin{array}{c}\mathrm{T} \\
\text { Hourly averages }\end{array}$} \\
\hline & Minimum & Maximum & Minimum & Maximum & Minimum & Maximum & Minimum & Maximum \\
\hline Methanol & 1.007 & 2.842 & 1.779 & 6.180 & 0.405 & 1.397 & 1.489 & 3.307 \\
\hline Ethanol & 0.483 & 2.963 & 0.646 & 4.526 & 0.214 & 1.120 & 0.392 & 1.898 \\
\hline Acetone/Propanal & 0.792 & 1.774 & 0.936 & 2.366 & 0.323 & 0.699 & 0.842 & 1.607 \\
\hline Acetaldehyde & 0.261 & 0.820 & 0.243 & 1.316 & 0.139 & 0.417 & 0.205 & 0.624 \\
\hline Acetic acid & 0.309 & 1.853 & 0.441 & 2.888 & 0.062 & 0.593 & 0.335 & 1.321 \\
\hline Isoprene & 0.018 & 0.084 & 0.019 & 0.121 & 0.012 & 0.035 & 0.023 & 0.059 \\
\hline MVK/MACR & 0.012 & 0.054 & 0.010 & 0.101 & 0.006 & 0.026 & 0.011 & 0.040 \\
\hline Monoterpenes & 0.005 & 0.069 & 0.004 & 0.093 & 0.003 & 0.033 & 0.005 & 0.075 \\
\hline Benzene & 0.120 & 0.217 & 0.074 & 0.217 & 0.098 & 0.151 & 0.104 & 0.183 \\
\hline Toluene & 0.083 & 0.530 & 0.044 & 0.764 & 0.026 & 0.133 & 0.049 & 0.319 \\
\hline C8 aromatics & 0.041 & 0.329 & 0.023 & 0.464 & 0.013 & 0.064 & 0.023 & 0.187 \\
\hline Acetonitrile & 0.064 & 0.109 & 0.100 & 0.141 & 0.034 & 0.056 & 0.079 & 0.111 \\
\hline
\end{tabular}

Table 5. VOC mixing ratios (ppbv) in the urban areas reported in the literature compared to those reported in this study for Barcelona. Values shown are averages or ranges of average values.

\begin{tabular}{|c|c|c|c|c|c|c|c|c|c|c|}
\hline Location & Period & Benzene & Toluene & $\mathrm{C} 8$ aromatics & Acetaldehyde & Acetone & Acetonitrile & Isoprene & Monoterpenes & Reference \\
\hline Caracas (Venezuela) & 1999-2000 & 1.1 & 3.2 & 3.7 & & & & & & Holzinger et al. $(2001 b)^{1}$ \\
\hline Other urban sites & various & $1.9-6$ & $5.7-14.3$ & $2.4-15.8$ & & & & & & Holzinger et al. (2001b) \\
\hline London (UK) & Oct 2006 & 0.14 & 1.85 & 0.16 & 3.57 & 1.57 & 0.33 & 0.17 & & Langford et al. (2010) \\
\hline Manchester (UK) & Jun 2006 & 0.1 & 0.2 & & 1.2 & 1.1 & & 0.3 & & Langford et al. (2009) \\
\hline Mexico City (Mexico) & Mar 2006 & & $3-28$ & & $3-12$ & & $0.25-1.4$ & $0.4-2$ & $0.3-2$ & Fortner et al. $(2009)^{2}$ \\
\hline Pearl River Delta (China) & Oct 2004 & 2.39 & 7.01 & 3.14 & & & 0.66 & 0.22 & & Liu et al. (2008) \\
\hline Los Angeles, CA (USA) & Sep 1993 & & & & 4 & 1.6 & & & & Grosjean et al. (1996) \\
\hline Brazilian Cities & various & & & & $1.9-24.2$ & & & & & Grosjean et al. (2002) \\
\hline Barcelona & winter 2009 & $0.22-0.59$ & $0.8-2.71$ & $0.86-3.39$ & $0.8-1.69$ & $1.13-1.65$ & $0.21-0.46$ & $0.18-0.32$ & $0.28-0.58$ & This study \\
\hline
\end{tabular}

1 These values correspond only to $11-16 \mathrm{~h}$ local time.

${ }^{2}$ Approximate values taken from graphs.

and although at a decreased speed, a new air mass arrived at MSY, as indicated by a change in absolute humidity of the air (Fig. 4). This air mass contained many VOCs, as indicated by most of the mixing ratio peaks. Many of the VOCs even reached their maximum hourly average mixing ratio of all the scenarios at MSY (Table 4): isoprene and MVK/MACR (0.1 ppbv), toluene ( $0.7 \mathrm{ppbv})$, methanol (6.1 ppbv), ethanol (4.5 ppbv), acetone ( $2.3 \mathrm{ppbv})$, acetaldehyde (1.3 ppbv) and acetic acid ( $2.8 \mathrm{ppbv})$. This peak on 13 March might be related to evening arrival of air from the west and northnortheast, uncoupled from the surface air circulation, that occurs on some days and have been identified in back trajectory model simulations (Jorba et al., 2011). However, low evening wind speeds and the low PBL during scenario B, and thus a probable lack of advection of air from the polluted PBL by those westerly and northerly air masses, points to a possible local origin (within a few kilometers) of the air mass loaded with VOCs and $\mathrm{NO}_{2}$. Furthermore, the benzene : toluene ratio of the peak on 13 March was 0.27, suggesting a lower level of atmospheric processing of the air mass. Similar situations and their effect on VOC mixing ratios might also occur in the atmospheric daily averages of the other scenarios in the form of an evening peak in mixing ratios, although the effects may be somewhat masked by the higher mixing ratios of VOCs already present at MSY under these other scenarios (A, C, and T). As examples, the mixing ratios of isoprene (Fig. 6) and of toluene and benzene (Fig. 8) increased around 17:00-18:00 UTC.

\subsubsection{Scenario C}

Scenario $\mathrm{C}$ was characterized by Atlantic advections that replaced the polluted air masses with clean Atlantic air. High northerly wind speeds (Fig. 4) thus prevented the VOC mixing ratios from presenting a clear diurnal cycle at either $\mathrm{BCN}$ or MSY. Only $\mathrm{NO}_{\mathrm{x}}$, especially $\mathrm{NO}_{2}$, showed a clear diurnal cycle at $\mathrm{BCN}$, with peaks in the morning and evening (Fig. 5). Only monoterpenes, benzene and some oxVOCs showed weak diurnal cycles at MSY but still had the lowest daytime mixing ratios of any scenario (Figs. 6-8 and Table 4). 


\section{Summary and conclusions}

We measured VOC mixing ratios concurrently at an urban $(\mathrm{BCN})$ and a rural (MSY) site in the Western Mediterranean Basin during the winter DAURE campaign. All VOC mixing ratios measured were generally higher at the urban site. The average VOC diurnal patterns differed between the sites, with the highest mixing ratios of most of the urban VOCs occurring in the morning and evening. These peaks coincided with rush hour, indicating that traffic is the main source of most of the VOCs analyzed. Also, between these two peaks, the daytime sea breezes transported the urban air inland, thus helping to decrease the VOC loading at the urban site. At the rural site, apart from biogenic isoprenoids that were mainly emitted locally in the MSY valley, most of the measured VOCs were advected by the sea breeze during the central part of the day, yielding the highest daily VOC mixing ratios.

The different atmospheric scenarios identified throughout the campaign had a clear influence on the VOC mixing ratios measured at both sites. Scenario A was characterized by the accumulation of air masses during a few days at a regional or continental scale. Both sites were within the PBL, and the sea breezes transported air parcels from the coastal regions (BCN) inland (MSY). Scenario B showed strong thermal inversions that decoupled the atmospheres of the two sites, leading to high mixing ratios of VOCs at the urban site and a lack of transport of coastal air masses to the MSY site, which was above the PBL. VOC mixing ratios at MSY were thus generally low, except when evening episodes of northerly wind advected air masses that may have contained high loads of VOCs. Finally, scenario C produced a cleansing of the VOC loads in the air at both sites by advecting clean Atlantic air.

The results of this study highlight the differences and relationships in VOC mixing ratios between nearby urban and rural areas in a Mediterranean region. Further research in other areas is warranted to gain better knowledge of the mutual influence from urban-rural areas on atmospheric VOC mixing ratios under different atmospheric physical conditions.

\section{Supplementary material related to this article is available online at: http://www.atmos-chem-phys.net/13/ 4291/2013/acp-13-4291-2013-supplement.pdf.}

Acknowledgements. This study was supported by the Spanish Government grants CGL2006-04025/BOS, CGL2010-17172, Consolider-Ingenio Montes CSD2008-00040 and Acción Complementaria DAURE CGL2007-30502-E/CLI, and the Catalan Government grant SGR 2009-458. Roger Seco was partially supported by an FPI fellowship (BES-2005-6989) from the Spanish Government and by a postdoctoral grant from Fundación Ramón Areces.

This research has received funding from the EC Seventh Framework Programme under grant agreement no. 215072 (Marie Curie Initial
Training Network, “CLOUD-ITN”). Helpful discussion concerning the PTR-TOF evaluation with Martin Graus and Ralf Schnitzhofer from the University of Innsbruck was much appreciated.

The National Center for Atmospheric Research is sponsored by the National Science Foundation.

Edited by: A. Hofzumahaus

\section{References}

Ajuntament de Barcelona: Dades bàsiques 2006, Direcció de serveis de mobilitat, Barcelona, Spain, 2007.

Arneth, A., Harrison, S. P., Zaehle, S., Tsigaridis, K., Menon, S., Bartlein, P. J., Feichter, J., Korhola, A., Kulmala, M., O’Donnell, D., Schurgers, G., Sorvari, S., and Vesala, T.: Terrestrial biogeochemical feedbacks in the climate system, Nature Geosci., 3, 525-532, doi:10.1038/ngeo905, 2010.

Atkinson, R.: Atmospheric chemistry of VOCs and $\mathrm{NO}_{\mathrm{x}}$, Atmos. Environ., 34, 2063-2101, doi:10.1016/S1352-2310(99)00460-4, 2000.

Baldwin, I. T., Halitschke, R., Paschold, A., von Dahl, C. C., and Preston, C. A.: Volatile signaling in plant-plant interactions: "Talking trees" in the genomics era, Science, 311, 812-815, doi:10.1126/science.1118446, 2006.

Barletta, B., Meinardi, S., Sherwood Rowland, F., Chan, C., Wang, X., Zou, S., Yin Chan, L., and Blake, D. R.: Volatile organic compounds in 43 Chinese cities, Atmos. Environ., 39, 5979-5990, doi:10.1016/j.atmosenv.2005.06.029, 2005.

Borbon, A., Fontaine, H., Veillerot, M., Locoge, N., Galloo, J. C., and Guillermo, R.: An investigation into the traffic-related fraction of isoprene at an urban location, Atmos. Environ., 35, 37493760, 2001.

Chebbi, A. and Carlier, P.: Carboxylic acids in the troposphere, occurrence, sources, and sinks: A review, Atmos. Environ., 30 , 4233-4249, 1996.

Davison, B., Taipale, R., Langford, B., Misztal, P., Fares, S., Matteucci, G., Loreto, F., Cape, J. N., Rinne, J., and Hewitt, C. N.: Concentrations and fluxes of biogenic volatile organic compounds above a Mediterranean macchia ecosystem in western Italy, Biogeosciences, 6, 1655-1670, doi:10.5194/bg-6-16552009, 2009.

de Gouw, J. and Warneke, C.: Measurements of volatile organic compounds in the Earth's atmosphere using proton-transferreaction mass spectrometry, Mass Spectrom. Rev., 26, 223-257, doi:10.1002/mas.20119, 2007.

de Gouw, J., Warneke, C., Karl, T., Eerdekens, G., van der Veen, C., and Fall, R.: Sensitivity and specificity of atmospheric trace gas detection by proton-transfer-reaction mass spectrometry, Int. J. Mass Spectrom., 223, 365-382, doi:10.1016/S13873806(02)00926-0, 2003.

Díaz-de-Quijano, M., Peñuelas, J., and Ribas, A.: Increasing interannual and altitudinal ozone mixing ratios in the Catalan Pyrenees, Atmos. Environ., 43, 6049-6057, doi:10.1016/j.atmosenv.2009.08.035, 2009.

Díaz-de-Quijano, M., Peñuelas, J., and Ribas, A.: Trends of AOT40 at three sites in the Catalan Pyrenees over the last 16 years, J. Atmos. Chem., 68, 317-330, doi:10.1007/s10874-012-9222-9, 2011. 
Díaz-de-Quijano, M., Schaub, M., Bassin, S., Volk, M., and Peñuelas, J.: Ozone visible symptoms and reduced root biomass in the subalpine species Pinus uncinata after two years of free-air ozone fumigation, Environ. Pollut., 169, 250-257, doi:10.1016/j.envpol.2012.02.011, 2012.

Evtyugina, M. G., Nunes, T., Alves, C., and Marques, M. C.: Photochemical pollution in a rural mountainous area in the northeast of Portugal, Atmos. Res., 92, 151-158, doi:10.1016/j.atmosres.2008.09.006, 2009.

Filella, I. and Peñuelas, J.: Daily, weekly, and seasonal time courses of VOC concentrations in a semi-urban area near Barcelona, Atmos. Environ., 40, 7752-7769, 2006.

Filella, I., Peñuelas, J., and Seco, R.: Short-chained oxygenated VOC emissions in Pinus halepensis in response to changes in water availability, Acta Physiol. Plant., 31, 311-318, doi:10.1007/s11738-008-0235-6, 2009.

Fortner, E. C., Zheng, J., Zhang, R., Berk Knighton, W., Volkamer, R. M., Sheehy, P., Molina, L., and André, M.: Measurements of Volatile Organic Compounds Using Proton Transfer Reaction - Mass Spectrometry during the MILAGRO 2006 Campaign, Atmos. Chem. Phys., 9, 467-481, doi:10.5194/acp-9-467-2009, 2009.

Fowler, D., Pilegaard, K., Sutton, M. A., Ambus, P., Raivonen, M., Duyzer, J., Simpson, D., Fagerli, H., Fuzzi, S., Schjoerring, J. K., Granier, C., Neftel, A., Isaksen, I. S. A., Laj, P., Maione, M., Monks, P. S., Burkhardt, J., Daemmgen, U., Neirynck, J., Personne, E., Wichink-Kruit, R., Butterbach-Bahl, K., Flechard, C., Tuovinen, J. P., Coyle, M., Gerosa, G., Loubet, B., Altimir, N., Gruenhage, L., Ammann, C., Cieslik, S., Paoletti, E., Mikkelsen, T. N., Ro-Poulsen, H., Cellier, P., Cape, J. N., Horvath, L., Loreto, F., Niinemets, Ü., Palmer, P. I., Rinne, J., Misztal, P., Nemitz, E., Nilsson, D., Pryor, S., Gallagher, M. W., Vesala, T., Skiba, U., Brueggemann, N., Zechmeister-Boltenstern, S., Williams, J., O'Dowd, C., Facchini, M. C., de Leeuw, G., Flossman, A., Chaumerliac, N., and Erisman, J. W.: Atmospheric composition change: Ecosystems-Atmosphere interactions, Atmos. Environ., 43, 5193-5267, doi:10.1016/j.atmosenv.2009.07.068, 2009.

Friedrich, R. and Obermeier, A.: Anthropogenic emissions of VOCs, in: Reactive Hydrocarbons in the Atmosphere, Hewitt, C. N. (Ed.), Academic Press, San Diego, CA, USA, 1-39, 1999.

Gimeno, B. S., Peñuelas, J., Porcuna, J. L., and Reinert, R. A.: Biomonitoring ozone phytotoxicity in eastern Spain, Water Air Soil Pollut., 85, 1521-1526, 1995.

Graus, M., Müller, M., and Hansel, A.: High Resolution PTRTOF: Quantification and Formula Confirmation of VOC in Real Time, J. Am. Soc. Mass Spectrom., 21, 1037-1044, doi:10.1016/j.jasms.2010.02.006, 2010.

Grosjean, D., Grosjean, E., and Moreira, L. F. R.: Speciated ambient carbonyls in Rio de Janeiro, Brazil, Environ. Sci. Technol., 36, 1389-1395, doi:10.1021/es0111232, 2002.

Grosjean, E., Grosjean, D., Fraser, M. P., and Cass, G. R.: Air quality model evaluation data for organics.2. C-1-C-14 carbonyls in Los Angeles air, Environ. Sci. Technol., 30, 2687-2703, doi:10.1021/es950758w, 1996.

Guenther, A., Karl, T., Harley, P., Wiedinmyer, C., Palmer, P. I., and Geron, C.: Estimates of global terrestrial isoprene emissions using MEGAN (Model of Emissions of Gases and Aerosols from Nature), Atmos. Chem. Phys., 6, 3181-3210, doi:10.5194/acp-6-
3181-2006, 2006.

Guerra, G., Iemma, A., Lerda, D., Martines, C., Salvi, G., and Tamponi, M.: Benzene Emissions from Motor-Vehicle Traffic in the Urban Area of Milan - Hypothesis of Health Impact Assessment, Atmos. Environ., 29, 3559-3569, doi:10.1016/13522310(95)00205-D, 1995.

Guo, H., Ling, Z. H., Cheung, K., Jiang, F., Wang, D. W., Simpson, I. J., Wang, T. J., Wang, X. M., Saunders, S. M., and Blake, D. R.: Characterization of photochemical pollution at different elevations in mountainous areas in Hong Kong, Atmos. Chem. Phys. Discuss., 12, 29025-29067, doi:10.5194/acpd-12-290252012, 2012.

Heeb, N. V., Forss, A. M., Bach, C., Reimann, S., Herzog, A., and Jackle, H. W.: A comparison of benzene, toluene and C-2benzenes mixing ratios in automotive exhaust and in the suburban atmosphere during the introduction of catalytic converter technology to the Swiss Car Fleet, Atmos. Environ., 34, 31033116, doi:10.1016/S1352-2310(99)00446-X, 2000.

Heil, M. and Kost, C.: Priming of indirect defences, Ecol. Lett., 9, 813-817, doi:10.1111/j.1461-0248.2006.00932.x, 2006.

Hellén, H., Tykkä, T., and Hakola, H.: Importance of monoterpenes and isoprene in urban air in northern Europe, Atmos. Environ., 59, 59-66, doi:10.1016/j.atmosenv.2012.04.049, 2012.

Holzinger, R., Jordan, A., Hansel, A., and Lindinger, W.: Automobile emissions of acetonitrile: Assessment of its contribution to the global source, J. Atmos. Chem., 38, 187-193, 2001a.

Holzinger, R., Kleiss, B., Donoso, L., and Sanhueza, E.: Aromatic hydrocarbons at urban, sub-urban, rural (8 degrees $52^{\prime} \mathrm{N}$; 67 degrees $19^{\prime} \mathrm{W}$ ) and remote sites in Venezuela, Atmos. Environ., 35, 4917-4927, doi:10.1016/S1352-2310(01)00286-2, 2001b.

Hsieh, C., Chang, K., and Kao, Y.: Estimating the ozone formation potential of volatile aromatic compounds in vehicle tunnels, Chemosphere, 39, 1433-1444, doi:10.1016/S00456535(99)00045-4, 1999.

Jacob, D. J., Field, B. D., Li, Q. B., Blake, D. R., de Gouw, J., Warneke, C., Hansel, A., Wisthaler, A., Singh, H. B., and Guenther, A.: Global budget of methanol: Constraints from atmospheric observations, J. Geophys. Res., 110, D08303, doi:10.1029/2004JD005172, 2005.

Jorba, O., Pandolfi, M., Spada, M., Baldasano, J. M., Pey, J., Alastuey, A., Arnold, D., Sicard, M., Artiñano, B., Revuelta, M. A., and Querol, X.: The DAURE field campaign: meteorological overview, Atmos. Chem. Phys. Discuss., 11, 4953-5001, doi:10.5194/acpd-11-4953-2011, 2011.

Jordan, C., Fitz, E., Hagan, T., Sive, B., Frinak, E., Haase, K., Cottrell, L., Buckley, S., and Talbot, R.: Long-term study of VOCs measured with PTR-MS at a rural site in New Hampshire with urban influences, Atmos. Chem. Phys., 9, 4677-4697, doi:10.5194/acp-9-4677-2009, 2009.

Karl, T., Hansel, A., Mark, T., Lindinger, W., and Hoffmann, D.: Trace gas monitoring at the Mauna Loa Baseline observatory using proton-transfer reaction mass spectrometry, Int. J. Mass Spectrom., 223, 527-538, 2003.

Kavouras, I. G., Mihalopoulos, N., and Stephanou, E. G.: Formation of atmospheric particles from organic acids produced by forests, Nature, 395, 683-686, 1998.

Kegge, W. and Pierik, R.: Biogenic volatile organic compounds and plant competition, Trends Plant Sci., 15, 126-132, doi:10.1016/j.tplants.2009.11.007, 2010. 
Kessler, A. and Baldwin, I. T.: Defensive function of herbivoreinduced plant volatile emissions in nature, Science, 291, 21412144, 2001.

Kulmala, M., Suni, T., Lehtinen, K. E. J., Dal Maso, M., Boy, M., Reissell, A., Rannik, Ü., Aalto, P., Keronen, P., Hakola, H., Bäck, J., Hoffmann, T., Vesala, T., and Hari, P.: A new feedback mechanism linking forests, aerosols, and climate, Atmos. Chem. Phys., 4, 557-562, doi:10.5194/acp-4-557-2004, 2004.

Langebner, S. et al:: Ambient VOC Measurements by GC-PTRTOF, in preparation, 2013.

Langford, B., Davison, B., Nemitz, E., and Hewitt, C. N.: Mixing ratios and eddy covariance flux measurements of volatile organic compounds from an urban canopy (Manchester, UK), Atmos. Chem. Phys., 9, 1971-1987, doi:10.5194/acp-9-1971-2009, 2009.

Langford, B., Nemitz, E., House, E., Phillips, G. J., Famulari, D., Davison, B., Hopkins, J. R., Lewis, A. C., and Hewitt, C. N.: Fluxes and concentrations of volatile organic compounds above central London, UK, Atmos. Chem. Phys., 10, 627-645, doi:10.5194/acp-10-627-2010, 2010.

Lappalainen, H. K., Sevanto, S., Bäck, J., Ruuskanen, T. M., Kolari, P., Taipale, R., Rinne, J., Kulmala, M., and Hari, P.: Daytime concentrations of biogenic volatile organic compounds in a boreal forest canopy and their relation to environmental and biological factors, Atmos. Chem. Phys., 9, 5447-5459, doi:10.5194/acp-9-5447-2009, 2009.

Lindinger, W., Hansel, A., and Jordan, A.: On-line monitoring of volatile organic compounds at pptv levels by means of protontransfer-reaction mass spectrometry (PTR-MS) - Medical applications, food control and environmental research, Int. J. Mass Spectrom., 173, 191-241, 1998.

Lippmann, M.: Health-Effects of Tropospheric Ozone - Review of Recent Research Findings and their Implications to Ambient AirQuality Standards, J. Expo. Anal. Environ. Epidemiol., 3, 103129, 1993.

Liu, Y., Shao, M., Lu, S., Liao, C., Wang, J., and Chen, G.: Volatile organic compound (VOC) measurements in the pearl river delta (PRD) region, China, Atmos. Chem. Phys., 8, 15311545, doi:10.5194/acp-8-1531-2008, 2008.

Llusia, J. and Peñuelas, J.: Emission of volatile organic compounds by apple trees under spider mite attack and attraction of predatory mites, Exp. Appl. Acarol., 25, 65-77, 2001.

Llusia, J., Peñuelas, J., Seco, R., and Filella, I.: Seasonal changes in the daily emission rates of terpenes by Quercus ilex and the atmospheric concentrations of terpenes in the natural park of Montseny, NE Spain, J. Atmos. Chem., 69, 215-230, doi:10.1007/s10874-012-9238-1, 2012.

Minguillón, M. C., Perron, N., Querol, X., Szidat, S., Fahrni, S. M., Alastuey, A., Jimenez, J. L., Mohr, C., Ortega, A. M., Day, D. A., Lanz, V. A., Wacker, L., Reche, C., Cusack, M., Amato, F., Kiss, G., Hoffer, A., Decesari, S., Moretti, F., Hillamo, R., Teinilä, K., Seco, R., Peñuelas, J., Metzger, A., Schallhart, S., Müller, M., Hansel, A., Burkhart, J. F., Baltensperger, U., and Prévôt, A. S. H.: Fossil versus contemporary sources of fine elemental and organic carbonaceous particulate matter during the DAURE campaign in Northeast Spain, Atmos. Chem. Phys., 11, 12067-12084, doi:10.5194/acp-11-12067-2011, 2011.

Mohr, C., DeCarlo, P. F., Heringa, M. F., Chirico, R., Slowik, J. G., Richter, R., Reche, C., Alastuey, A., Querol, X., Seco, R.,
Peñuelas, J., Jiménez, J. L., Crippa, M., Zimmermann, R., Baltensperger, U., and Prévôt, A. S. H.: Identification and quantification of organic aerosol from cooking and other sources in Barcelona using aerosol mass spectrometer data, Atmos. Chem. Phys., 12, 1649-1665, doi:10.5194/acp-12-1649-2012, 2012.

Monteiro, A., Strunk, A., Carvalho, A., Tchepel, O., Miranda, A. I., Borrego, C., Saavedra, S., Rodriguez, A., Souto, J., Casares, J., Friese, E., and Elbern, H.: Investigating a high ozone episode in a rural mountain site, Environ. Pollut., 162, 176-189, doi:10.1016/j.envpol.2011.11.008, 2012.

Moreno, T., Querol, X., Alastuey, A., Reche, C., Cusack, M., Amato, F., Pandolfi, M., Pey, J., Richard, A., Prévôt, A. S. H., Furger, M., and Gibbons, W.: Variations in time and space of trace metal aerosol concentrations in urban areas and their surroundings, Atmos. Chem. Phys., 11, 9415-9430, doi:10.5194/acp-11-94152011, 2011.

Müller, M., Graus, M., Ruuskanen, T. M., Schnitzhofer, R., Bamberger, I., Kaser, L., Titzmann, T., Hörtnagl, L., Wohlfahrt, G., Karl, T., and Hansel, A.: First eddy covariance flux measurements by PTR-TOF, Atmos. Meas. Tech., 3, 387-395, doi:10.5194/amt-3-387-2010, 2010.

Pacifico, F., Harrison, S. P., Jones, C. D., and Sitch, S.: Isoprene emissions and climate, Atmos. Environ., 43, 6121-6135, doi:10.1016/j.atmosenv.2009.09.002, 2009.

Pandolfi, M., Querol, X., Alastuey, A., Jimenez, J. L., Cusack, M., Reche, C., Pey, J., Mohr, C., DeCarlo, P., Prévôt, A., Baltensperger, U., Artiñano, B., Baldasano, J. M., Jorba, O., Burkhart, J., Hansel, A., Schallhart, S., Müller, M., Metzger, A., Ortega, A., Saarikoski, S., Cubison, M., Ng, S., Lorente, J., Nemitz, E., di Marco, C., Peñuelas, J., Sicard, M., Comeron, A., Amato, F., Moreno, T., Viana, M., Pérez, N., Moreno, N., Seco, R., Filella, I., Llusià, J., Piot, M., and Pay, M. T.: Source and origin of PM in the Western Mediterranean Basin: An overview of the DAURE campaign. Atmos. Chem. Phys. Discuss., in preparation, 2013.

Peñuelas, J. and Llusia, J.: The complexity of factors driving volatile organic compound emissions by plants, Biol. Plantarum, 44, 481-487, 2001.

Peñuelas, J. and Llusia, J.: Linking photorespiration, monoterpenes and thermotolerance in Quercus, New Phytol., 155, 227-237, 2002.

Peñuelas, J. and Llusia, J.: BVOCs: plant defense against climate warming?, Trends Plant Sci., 8, 105-109, 2003.

Peñuelas, J. and Munné-Bosch, S.: Isoprenoids: an evolutionary pool for photoprotection, Trends Plant Sci., 10, 166-169, 2005.

Peñuelas, J. and Staudt, M.: BVOCs and global change, Trends Plant Sci., 15, 133-144, doi:10.1016/j.tplants.2009.12.005, 2010.

Peñuelas, J., Llusia, J., Asensio, D., and Munné-Bosch, S.: Linking isoprene with plant thermotolerance, antioxidants and monoterpene emissions, Plant Cell Environ., 28, 278-286, 2005.

Peñuelas, J., Filella, I., Seco, R., and Llusia, J.: Increase in isoprene and monoterpene emissions after re-watering of droughted Quercus ilex seedlings, Biol. Plantarum, 53, 351-354, doi:10.1007/s10535-009-0065-4, 2009.

Pérez, N., Pey, J., Castillo, S., Viana, M., Alastuey, A., and Querol, $\mathrm{X}$.: Interpretation of the variability of levels of regional background aerosols in the Western Mediterranean, Sci. Total Environ., 407, 527-540, doi:10.1016/j.scitotenv.2008.09.006, 2008. 
Pichersky, E. and Gershenzon, J.: The formation and function of plant volatiles: perfumes for pollinator attraction and defense, Curr. Opin. Plant Biol., 5, 237-243, 2002.

Pierik, R., Visser, E. J. W., De Kroon, H., and Voesenek, L. A. C. J.: Ethylene is required in tobacco to successfully compete with proximate neighbours, Plant Cell Environ., 26, 1229-1234, 2003.

Possanzini, M., Di Palo, V., and Cecinato, A.: Sources and photodecomposition of formaldehyde and acetaldehyde in Rome ambient air, Atmos. Environ., 36, 3195-3201, 2002.

Reche, C., Viana, M., Amato, F., Alastuey, A., Moreno, T., Hillamo, R., Teinilä, K., Saarnio, K., Seco, R., Peñuelas, J., Mohr, C., Prévôt, A. S. H., and Querol, X.: Biomass burning contributions to urban aerosols in a coastal Mediterranean City, Sci. Total Environ., 427-428, 175-190, doi:10.1016/j.scitotenv.2012.04.012, 2012.

Ribas, A. and Peñuelas, J.: Temporal patterns of surface ozone levels in different habitats of the North Western Mediterranean basin, Atmos. Environ., 38, 985-992, doi:10.1016/j.atmosenv.2003.10.045, 2004.

Ribas, A. and Peñuelas, J.: Surface ozone mixing ratio increase with altitude in a transect in the Catalan Pyrenees, Atmos. Environ., 40, 7308-7315, doi:10.1016/j.atmosenv.2006.06.039, 2006.

Ribas, A., Peñuelas, J., Elvira, S. and Gimeno, B. S.: Ozone exposure induces the activation of leaf senescence-related processes and morphological and growth changes in seedlings of Mediterranean tree species, Environ. Pollut., 134, 291-300, doi:10.1016/j.envpol.2004.07.026, 2005.

Sanz, M. J., Calatayud, V., and Calvo, E.: Spatial pattern of ozone injury in Aleppo pine related to air pollution dynamics in a coastal-mountain region of eastern Spain, Environ. Poll., 108, 239-247, doi:10.1016/S0269-7491(99)00182-7, 2000.

Seco, R., Peñuelas, J., and Filella, I.: Short-chain oxygenated VOCs: Emission and uptake by plants and atmospheric sources, sinks, and concentrations, Atmos. Environ., 41, 2477-2499, doi:10.1016/j.atmosenv.2006.11.029, 2007.

Seco, R., Peñuelas, J. and Filella, I.: Formaldehyde emission and uptake by Mediterranean trees Quercus ilex and Pinus halepensis, Atmos. Environ., 42, 7907-7914, doi:10.1016/j.atmosenv.2008.07.006, 2008.

Seco, R., Filella, I., Llusia, J., and Peñuelas, J.: Methanol as a signal triggering isoprenoid emissions and photosynthetic performance in Quercus ilex, Acta Physiol. Plant., 33, 2413-2422, doi:10.1007/s11738-011-0782-0, 2011a.

Seco, R., Peñuelas, J., Filella, I., Llusia, J., Molowny-Horas, R., Schallhart, S., Metzger, A., Müller, M. and Hansel, A.: Contrasting winter and summer VOC mixing ratios at a forest site in the Western Mediterranean Basin: the effect of local biogenic emissions, Atmos. Chem. Phys., 11, 13161-13179, doi:10.5194/acp11-13161-2011, 2011b.

Sillman, S.: The relation between ozone, NOx and hydrocarbons in urban and polluted rural environments, Atmos. Environ., 33, 1821-1845, doi:10.1016/S1352-2310(98)00345-8, 1999.

Singh, H. B., Salas, L. J., Chatfield, R. B., Czech, E., Fried, A., Walega, J., Evans, M. J., Field, B. D., Jacob, D. J., Blake, D., Heikes, B., Talbot, R., Sachse, G., Crawford, J. H., Avery, M. A., Sandholm, S., and Fuelberg, H.: Analysis of the atmospheric distribution, sources, and sinks of oxygenated volatile organic chemicals based on measurements over the Pacific during TRACE-P, J. Geophys. Res., 109, D15S07,
doi:10.1029/2003JD003883, 2004.

Singsaas, E. L. and Sharkey, T. D.: The regulation of isoprene emission responses to rapid leaf temperature fluctuations, Plant Cell Environ., 21, 1181-1188, 1998.

Spirig, C., Neftel, A., Ammann, C., Dommen, J., Grabmer, W., Thielmann, A., Schaub, A., Beauchamp, J., Wisthaler, A., and Hansel, A.: Eddy covariance flux measurements of biogenic VOCs during ECHO 2003 using proton transfer reaction mass spectrometry, Atmos. Chem. Phys., 5, 465-481, doi:10.5194/acp-5-465-2005, 2005.

Steinbacher, M., Dommen, J., Ordonez, C., Reimann, S., Gruebler, F. C., Staehelin, J., and Prévôt, A. S. H.: Volatile organic compounds in the Po Basin. part A: Anthropogenic VOCs, J. Atmos. Chem., 51, 271-291, doi:10.1007/s10874-005-3576-1, 2005.

Terradas, J.: Holm oak and holm oak forest: an introduction, in: Ecology of Mediterranean evergreen oak forests, edited by: Rodà, F., Retana, J., Gracia, C. A., and Bellot, J., Springer, Berlin, 3-14, 1999.

Tsai, D., Wang, M., Wang, C., and Chan, C.: A study of groundlevel ozone pollution, ozone precursors and subtropical meteorological conditions in central Taiwan, J. Environ. Monit., 10, 109-118, doi:10.1039/b714479b, 2008.

Tunved, P., Hansson, H. C., Kerminen, V. M., Strom, J., Dal Maso, M., Lihavainen, H., Viisanen, Y., Aalto, P. P., Komppula, M., and Kulmala, M.: High natural aerosol loading over boreal forests, Science, 312, 261-263, doi:10.1126/science.1123052, 2006.

Velikova, V., Pinelli, P., Pasqualini, S., Reale, L., Ferranti, F., and Loreto, F.: Isoprene decreases the concentration of nitric oxide in leaves exposed to elevated ozone, New Phytol., 166, 419-426, 2005.

Warneke, C., van der Veen, C., Luxembourg, S., de Gouw, J. A., and Kok, A.: Measurements of benzene and toluene in ambient air using proton-transfer-reaction mass spectrometry: calibration, humidity dependence, and field intercomparison, Int. J. Mass Spectrom., 207, 167-182, doi:10.1016/S1387-3806(01)00366-9, 2001.

Warneke, C., McKeen, S. A., de Gouw, J. A., Goldan, P. D., Kuster, W. C., Holloway, J. S., Williams, E. J., Lerner, B. M., Parrish, D. D., Trainer, M., Fehsenfeld, F. C., Kato, S., Atlas, E. L., Baker, A., and Blake, D. R.: Determination of urban volatile organic compound emission ratios and comparison with an emissions database, J. Geophys. Res.-Atmos., 112, D10S47, doi:10.1029/2006JD007930, 2007.

Wright, G. A. and Schiestl, F. P.: The evolution of floral scent: the influence of olfactory learning by insect pollinators on the honest signalling of floral rewards, Funct. Ecol., 23, 841-851, doi:10.1111/j.1365-2435.2009.01627.x, 2009.

Yamamoto, N., Okayasu, H., Murayama, S., Mori, S., Hunahashi, K., and Suzuki, K.: Measurement of volatile organic compounds in the urban atmosphere of Yokohama, Japan, by an automated gas chromatographic system, Atmos. Environ., 34, 4441-4446, doi:10.1016/S1352-2310(00)00168-0, 2000.

Zhao, J. and Zhang, R. Y.: Proton transfer reaction rate constants between hydronium ion $\left(\mathrm{H}_{3} \mathrm{O}^{+}\right)$and volatile organic compounds, Atmos. Environ., 38, 2177-2185, doi:10.1016/j.atmosenv.2004.01.019, 2004.

Ziomas, I. C.: The Mediterranean Campaign of Photochemical Tracers Transport and chemical evolution (MEDCAPHOTTRACE): An outline, Atmos. Environ., 32, 2045-2053, 1998. 